\title{
障壁まわりの乱流場口拡散場の LES解析 \\ LES Analysis on Turbulence and Dispersion Fields around a Normal Plate
}

\author{
田村哲郎*1 中山浩成*2 \\ Tetsuro TAMURA, Hiromasa NAKAYAMA
}

\section{SUMMARY}

Large-eddy simulation(LES) is applied to the problem of atmospheric dispersion around a normal plate for oncoming turbulence, which is time-sequentially generated by unsteady numerical simulation of spatially-developing boundary layer in the driver unit as another computational domain. The present numerical model is validated in comparison with the previous wind tunnel experimental data. Also, based on the computed data, we investigate turbulence and dispersion fields strongly influenced by complex dynamic behavior of separated shear layers and large eddies in the wake, and clarify physical mechanism of plume entrainment into the wake region of a normal plate.

keywords: large-eddy simulation, a normal plate, atmospheric dispersion, plume entrainment

\section{1. はじめに}

大気境界層中の工業施設などからの排ガス拡散現象 について、風洞実験や野外実験などにより、煙突の場合 だけでなく、建物そのものからの排ガスに関して、特に 後流域を対象に濃度特性が明らかにされてきている。 Robins ${ }^{1}$, Ogawa ${ }^{2)}$ ，老川 ${ }^{3)}$ らは、建物壁面からの排ガス に対して風向や煙源位置を变化させたときの平均濃度 を定量的に見積もり、Huber ${ }^{4)}$ らは建物影響を考慮して 後流域の拡散幅を推定し、その拡散幅に基づき平均濃 度分布を予測している。また、排ガスが臭気性を有する 場合、あるいは漏洩事故により有害性や可然性のガス が周辺に拡散された場合など、危険性の高いガスにつ いては時間平均濃度だけでなく、瞬間的に発生する高 濃度の評価もまた必要になる。 $\mathrm{Li}^{5)}$ 、老川 ${ }^{6)}$ 、佐藤 7 ら は風洞実験により建物周りの濃度変動場の構造や瞬間 最大濃度特性について検討している。
る場合も想定される。ここで、こういった障害物の存在 しない場合においては、従来の正規分布型プルームモ デル式により平均濃度の予測は容易であるものの、障 害物の存在する場合においては、背後で剥離せん断層 や後流渦により複雑な乱流場が形成されて拡散特性が 大きく影響を受けるため、従来モデルによる濃度予測 は困難となる。i $1 \operatorname{son}^{8)}$ らは建物上流側からの排ガスの 後流域における平均濃度場について建物が存在しない 場合と比較検討している。その結果、建物後方の地表近 傍の平均濃度は剥離域内にガスが連行され、建物が無 い場合に比べて高くなることなどを報告している。し かしながら、剥離域への連行が伴う拡散現象での強い 非定常性にもかかわらず、平均的評価に限られ、本来、 非定常な拡散挙動の物理機構を解明するには、乱流場 と拡散場の空間構造と両者の関連性に関する豊富な データに基づいた精査が必要となっている。

こうした現状を背景に、CFD (計算流体力学)による建

*1 東京工業大学 教授・工博 e-mail:tamura@depe.titech. ac.jp

Professor, Tokyo Institute of Technology, Dr.Eng.

*2 東京工業大学 大学院生·工修

Graduate Student, Tokyo Institute of Technology, M.Eng.

(原稿受理 : 2004年7月 30 日, 採用決定 : 2005年3月9日) 
物周辺における排ガス拡散問題に関する研究が、近年 の計算機能力の向上に伴い、急速に行われてきている。 現在、数值解析による最も実用的な排ガス拡散の予測 手法としてRANS (Reynolds Averaged Navier-Stokes) が挙げられる。この手法は、計算負荷は小さいものの、 建物屋根面、側面での循環流や後方の逆流などが存在 するような複雑な流れ場の再現性については十分では ないことが一般的に知られている。また、拡散場におい ても、乱流シュミット数を始めとして、輸送過程で重要 なモデル定数を経験的に与えて数值解析を実行してい るため、平均濃度についてはある程度定量的に再現さ れているものの ${ }^{9)}$ 、普遍的に確立された予測手法とは言 えない。さらに、乱流変動量のモデル化の概念 (アンサ ンブル平均・時間平均) に対して、標準型では計算結果 への時間平均量としての評価が避けられず、乱流粘性 に内在する特性から基本的に変動濃度の再現性は十分 とは言えない。特に漏洩事故などによる危険性物質の ピーク濃度の出現に対しては予測が困難であり、対象 とする拡散問題によってはその適用に限界がある。

それに対し、LES (Large-Eddy Simulation)は計算 負荷は高いものの、剥離現象や循環流など複雑な乱流 場に対しても十分に再現できる予測手法として挙げら れる。LESでは、空間平均を施すことにより、普遍的な 構造を有する小さい渦スケールをモデル化し、流れ場 の現象に支配的な大きいスケールの渦は直接計算を行 うため、詳細な乱流構造の把握やそれに基づく高濃度 出現の予測は可能である。また、方程式のモデル定数 は、乱流場・拡散場の性状に応じ、時間・空間の関数と して動的に評価することも可能であるため10),11)、種々 の複雑乱流場への適用性が高い予測手法であるものと 考えられる。現在、乱流境界層中における排ガス拡散現 象に対して LES が適用され、数值計算による詳細な濃 度変動場の構造の把握 ${ }^{12)}$ や瞬間高濃度の予測 ${ }^{13)}$ などが 可能な段階にきている。

本研究では、流れが剥離を伴い、非定常的な移流効果 が激しい障害物周りの上流側煙源に対する拡散問題に ついて LES の適用を考える。障害物の形状は、後流構 造の単純さを考慮して、地表面上に鉛直に立つ障壁を 選定し、接近流として空間的に発達する乱流境界層を 与える。まずLES によって得られた乱流場・拡散場に 関する計算結果を既往の風洞実験結果と比較し、本数 理モデルの精度検証を行い、その適用性について明ら かにする。さらに、障壁の後流域における剥離せん断層 の挙動と渦運動などの乱流場の構造とそれによって決 定される拡散特性を明らかにし、濃度分布の形成にあ たり重要な因子となる連行特性の観点から、後流域一 の乱流物質輸送の機構について考察する。

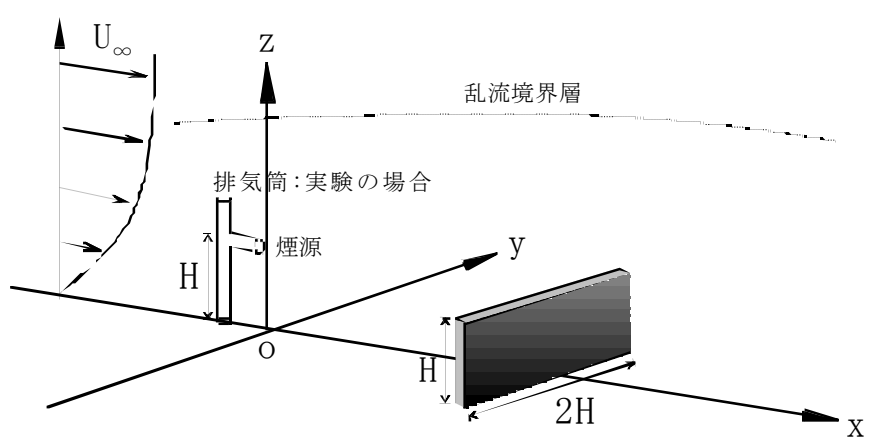

Fig. 1 Schematic of a normal plate

\section{2. 障壁周りの拡散現象のモデル}

図 1 に本研究で対象とする障壁周りの拡散現象のモ デルを示す。本研究では、障壁の存在が拡散場に与える 影響を調べるために、煙源を障壁の上流側で比較的近 い位置に設ける。また、障壁の形状は、後流での拡散特 性をそのまま吟味するためになるべく単純な長方形板 とし、水平および鉛直方向からの拡散物質の三次元的 な進入を考える。煙源高さおよび障壁高さは共に H と する。平地条件での点源拡散において煙源より $2 \mathrm{H}$ 下流 で得られる水平方向の平均濃度分布をガウス正規型と 仮定すると、プルーム中心軸から最大濃度の $1 \%$ 程度に なる位置までの拡がり幅は $3 \sigma \mathrm{y} （ \begin{gathered}0 \\ \mathrm{y}\end{gathered}$ と算出されたので、障壁半幅をそれよりやや広い $5 \sigma$ yとした。この障壁半幅5 0 y は、障壁高さHを用いて 換算すると $\mathrm{H}$ 程度になり、したがって、障壁幅は $2 \mathrm{H}$ と なる。本モデルでは、上記の障壁を乱流境界層中の地表 面に垂直に立て、後方での剥離流れによる強い非定常 性を持つ乱流特性の観点から拡散性状に与える影響に ついて調べ、従来より未解明であった後流域への拡散 物質の連行について明らかにする。座標系については 煙源を原点 $(\mathrm{o})$ に、主流方向を $\mathrm{x} 、$ 水平方向を $\mathrm{y} 、$ 鉛直方 向を $\mathrm{z}$ とする。なお、同じ障壁を対象にして、別途、風 洞実験 14),15) が実施され、乱流場・拡散場の詳細な統計 量が得られている。

\section{3. 数值計算手法}

\section{1 支配方程式と LES}

本研究では、LESによる数值解析を実行し、障壁の存 在しない平地条件では標準スマゴリンスキー16)を使用 し、障壁の存在する場合は流れ場および拡散場に対し てもダイナミックスマゴリンスキーモデル10),11)をそれ ぞれ使用している。

下記にグリッドフィルター操作をされた非圧縮性に 基づく連続の式、Navier-Stokes 運動方程式、物質拡 散方程式を示す。

$$
\frac{\partial \bar{u}_{i}}{\partial x_{i}}=0
$$




$$
\begin{aligned}
& \frac{\partial \bar{u}_{i}}{\partial t}+\frac{\partial \bar{u}_{i} \bar{u}_{j}}{\partial x_{j}}=-\frac{\partial \bar{p}}{\partial x_{i}}+\frac{\partial}{\partial x_{j}}\left(-\tau_{i j}+2 v \bar{S}_{i j}\right) \\
& \frac{\partial \bar{c}}{\partial t}+\frac{\partial \bar{c} \bar{u}_{j}}{\partial x_{j}}=-\frac{\partial}{\partial x_{j}} h_{j}
\end{aligned}
$$

ここで、 $\tau_{\mathrm{i} j}, \mathrm{~h}_{\mathrm{j}}$ および $\mathrm{S}_{\mathrm{ij}}$ はそれぞれサブグリッドス ケールのレイノルズ応力、乱流スカラーフラックス、歪 速度テンソルを表す。

$$
\begin{aligned}
\tau_{i j} & =\overline{u_{i} u_{j}}-\overline{u_{i} u_{j}} \\
h_{j} & =\overline{c u_{j}}-\bar{c} \overline{u_{j}} \\
\overline{S_{i j}} & =1 / 2\left(\partial \overline{u_{i}} / \partial x_{j}+\partial \overline{u_{j}} / \partial x_{i}\right)
\end{aligned}
$$

ここで、 $\tau_{i j}, h_{j}$ を標準型スマゴリンスキーモデルに 基づく渦粘性モデルにより近似する。

$$
\begin{aligned}
& \tau_{i j}-\frac{1}{3} \delta_{i j} \tau_{k k}=-2 v_{e} \overline{S_{i j}} \\
& v_{e}=\left(C_{s} f_{s} \bar{\Delta}\right)^{2}\left(2 \overline{S_{i j}} \overline{S_{i j}}\right)^{\frac{1}{2}} \\
& h_{j}=-\frac{v_{e}}{S c}\left(\frac{\partial \bar{c}}{\partial x_{j}}\right)
\end{aligned}
$$

ここで、 $\delta \mathrm{ij}, v \mathrm{e}, \mathrm{Cs}, \mathrm{fs}$ およびScはそれぞれクロ ネッカーデルタ関数、渦粘性、流れ場のモデル定数、Van Driest減衰関数、シュミット数を表す。また、Csは0.1、 $\mathrm{Sc}$ 数は 0.5 とし、グリッド幅は以下の通りである。

$$
\bar{\Delta}=\left(\bar{\Delta}_{x} \bar{\Delta}_{y} \bar{\Delta}_{z}\right)^{\frac{1}{3}}
$$

さらにテストフィルター操作を実行すると、非压縮 性のNavier-Stokes 運動方程式と物質拡散方程式は以 下のようになる。

$$
\begin{aligned}
& \frac{\partial \tilde{\bar{u}}_{i}}{\partial t}+\frac{\partial \tilde{\bar{u}}_{i} \tilde{\bar{u}}_{j}}{\partial x_{j}}=-\frac{\partial \tilde{\bar{p}}}{\partial x_{i}}+\frac{\partial}{\partial x_{j}}\left(-T_{i j}+2 v \tilde{\bar{S}}_{i j}\right) \\
& \frac{\partial \tilde{\bar{c}}}{\partial t}+\frac{\partial \tilde{\bar{c}} \tilde{\bar{u}}_{j}}{\partial x_{j}}=-\frac{\partial}{\partial x_{j}} H_{j} \\
& T_{i j}=\tilde{\widetilde{u_{i} u_{j}}}-\tilde{\widetilde{u_{i}}} \tilde{\tilde{u_{j}}} \\
& H_{j}=\tilde{\overline{c u_{j}}}-\simeq \widetilde{\bar{c}} \tilde{u_{j}}
\end{aligned}
$$

$\mathrm{T}_{\mathrm{ij}}, \mathrm{H}_{\mathrm{j}}$ は渦粘性近似により以下のようになる。

$$
\begin{aligned}
& T_{i j}-\frac{1}{3} \delta_{i j} T_{k k}=-2 C_{d} \tilde{\tilde{\bar{S}}^{2}} \tilde{\tilde{\bar{S}}} \tilde{\bar{S}}_{i j} \quad\left(\tilde{\bar{S}}=\sqrt{2 \tilde{\bar{S}}_{i j} \tilde{\bar{S}}_{i j}}\right) \\
& H_{j}=-C_{c} \tilde{\bar{\Delta}} 2 \tilde{\bar{S}} \frac{\partial \tilde{\bar{c}}}{\partial x_{j}}
\end{aligned}
$$

$$
\begin{aligned}
& \tau_{i j}-\frac{1}{3} \delta_{i j} \tau_{k k}=-2 C_{d} \bar{\Delta}^{2} \overline{S S_{i j}} \quad\left(\bar{S}=\sqrt{2 \bar{S}_{i j} \bar{S}_{i j}}\right) \\
& h_{j}=-C_{c} \bar{\Delta}^{2} \bar{S} \frac{\partial \bar{c}}{\partial x_{j}}
\end{aligned}
$$

ここで、テストフィルター幅は以下のように与えら れている。

$\tilde{\bar{\Delta}}=\left(\tilde{\bar{\Delta}}_{x} \tilde{\bar{\Delta}}_{y} \tilde{\bar{\Delta}}_{z}\right)^{\frac{1}{\beta}}$

$$
\left(\tilde{\bar{\Delta}}_{x}=2 \bar{\Delta}_{x}, \quad \tilde{\bar{\Delta}}_{y}=2 \bar{\Delta}_{y}, \quad \tilde{\bar{\Delta}}_{z}=2 \bar{\Delta}_{z}\right)
$$

$\mathrm{T}_{\mathrm{ij}}, \mathrm{H}_{\mathrm{j}}$ は直接計算できないが、ここでGernamo identityにより以下のように導出される。

$$
L_{i j}=T_{i j}-\tilde{\tau}_{i j}=\tilde{\bar{u}}_{i} \overline{\bar{u}}_{j}-\tilde{\bar{u}}_{i} \tilde{\bar{u}}_{j}
$$

$$
P_{j}=H_{j}-\tilde{h}_{j}=\tilde{\bar{u}}_{j} \overline{\bar{c}}-\tilde{\bar{u}}_{j} \tilde{\bar{c}}
$$

また、上式はそれぞれ以下のように変形できる。

$$
\begin{aligned}
& L_{i j}=2 C_{d}\left(-\tilde{\bar{\Delta}}^{2} \tilde{\bar{S}} \tilde{\bar{S}}_{i j}+\bar{\Delta}^{2} \widetilde{\bar{S}}_{i j}\right) \\
& P_{j}=C_{c}\left(-\tilde{\bar{\Delta}} 2 \tilde{\bar{S}} \frac{\partial \tilde{\bar{c}}}{\partial x_{j}}+\bar{\Delta}^{2} \overline{\frac{\partial}{\bar{c}}} \frac{\tilde{\partial x_{j}}}{j}\right)
\end{aligned}
$$

ここで、流れ場および拡散場のモデル定数 $\mathrm{Cd}, \mathrm{Cc}$ は ダイナミックモデルにより、下式より算出する。

$$
\begin{aligned}
& C_{d}=-\frac{L_{i j} M_{i j}}{M_{i j} M_{i j}}, \quad M_{i j}=2\left(\tilde{\bar{\Delta}^{2}} \tilde{\bar{S}} \tilde{\bar{S}}_{i j}-\widetilde{\Delta^{2}} \overline{\bar{S}} \bar{S}_{i j}\right) \\
& C_{c}=-\frac{P_{j} Q_{j}}{Q_{j} Q_{j}}, \quad Q_{j}=\tilde{\bar{\Delta}}^{2} \tilde{\tilde{S}} \frac{\partial \tilde{\bar{c}}}{\partial x_{j}}-\bar{\Delta}^{2} \overline{\bar{S}} \frac{\partial \bar{c}}{\partial x_{j}}
\end{aligned}
$$

\section{2 計算アルゴリズムと支配方程式の離散化}

流速と圧力のカップリングはMAC 法にしたがい、圧 力に関する Poisson 方程式の解法には SOR 法を用いて いる。流れ場について、空間微分項は 4 次精度中心差 分、時間進行法は 2 次精度Adams-Bashforth 法を用い ている。拡散場については、移流項はCIP を用い(数值 振動が生じた場合、1 次関数補間を適用 $\left.{ }^{17)}\right)$ 、拡散項は 4 次精度中心差分としている。

\section{4. 計算モデルの検証と考察}

\section{1 計算モデル}

図 2 に計算モデルについて示す。流入変動風を作成 するための (a) ドライバー部では計算領域として $26.7 \mathrm{H}$ $\times 20 \mathrm{H} \times 6.7 \mathrm{H}($ 主流 $\times$ 水平 $\times$ 鉛直方向、格子数: $200 \times$ $240 \times 100)$ （b) 解析対象部では $30 \mathrm{H} \times 20 \mathrm{H} \times 6.7 \mathrm{H}($ 格 子数： $360 \times 240 \times 100)$ としている。なお、本研究では 比較的短い吹送距離で境界層乱流の空間発達を目指す 


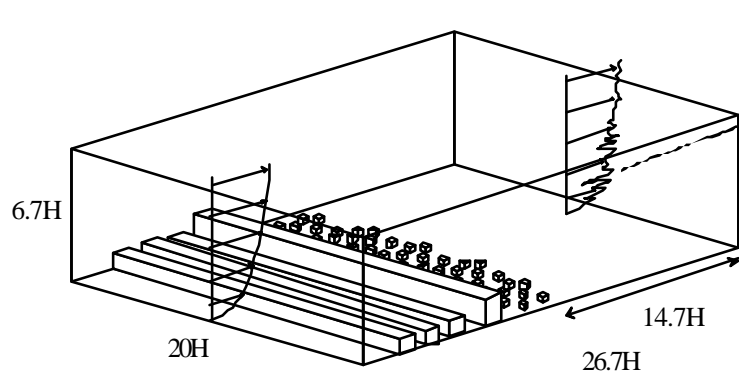

(a) ドライバー部

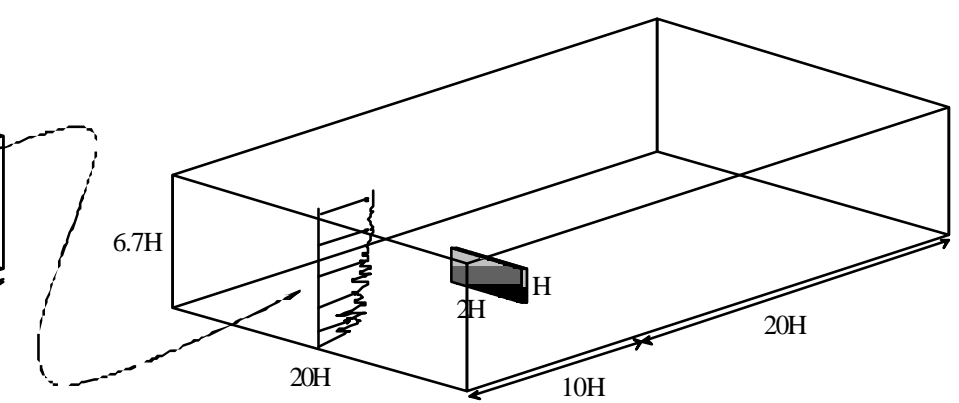

(b) 解析対象部

Fig. 2 Computational model for plume dispersion around a normal plate

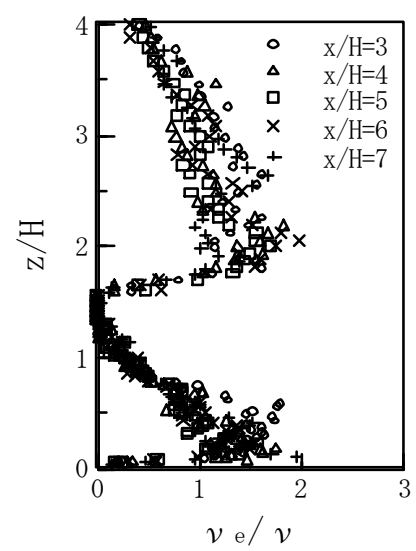

Fig. 3 Vertical profiles of eddy viscosity coefficients around a normal plate

ために、ドライバー部の流入境界は $1 / 7$ 勾配を持つ定 常流としている。また、分厚い境界層を作るために地表 面に高さ $0.5 \mathrm{H}$ 、幅 $0.5 \mathrm{H}$ の 2 次元ラフネスブロックを 3 本、その下流に高さ $0.7 \mathrm{H} 、$ 幅 $0.4 \mathrm{H}$ の 2 次元ラフネスブ ロックを 1 本設置し、さらに、乱流化を促進させるため に一辺 $0.5 \mathrm{H}$ の 3 次元ラフネスブロックを 40 個千鳥状 に与えている。なお、ドライバー部後方ではラフネスは 与えずに地表面を滑らかにし、滑面に対応した境界層 流れの再現をターゲットにしている。流出境界は移流 型境界条件としている。

以上のドライバー部で得られた境界層乱流をその流 出部より $1.3 \mathrm{H}$ 上流側にて計算ステップ毎に抽出して、 解析部の流入境界に与えている。流出部では移流型境 界としている。また、水平方向には周期境界、地表面お よび建物表面ではno-slip、上面ではfree-slip 条件 を用い、拡散場についてはいずれの境界面で濃度勾配 が 0 になるようにしている。なお、格子配置は主流・水 平方向については等間隔とし、鉛直方向については地 表近傍および障壁高さの $0.8 \sim 1.2$ 倍までは格子間隔 を狭め、それより上空では不等間隔としている。障壁は 解析対象部の流入境界より $10 \mathrm{H}$ 下流の位置に設置した。

次に、上述の計算モデルに基づき、ダイナミックスマ ゴリンスキーモデルにおけるモデル化の程度を調べる
ために、動粘性係数 $(v)$ とフィルター操作により発生 する渦粘性係数 $(v$ e $)$ との比を求め、それを図 3 に示す。 障壁後方での渦粘性係数の鉛直分布は、いずれの風下 位置においても地表近傍および障壁高さの 2 倍の所で ピークが見られ、その比の最大值はおおよそ 2 程度を 示す。ここで、坪倉ら ${ }^{18)}$ は、ダイナミックスマゴリン スキーモデルを用いて平板チャネル乱流解析を行って いる。その結果、ダイナミックモデルにより得られた動 粘性係数に対する渦粘性係数の比は $1 \sim 2$ 倍程度の值 であり、GS(グリッドスケール)成分でのレイノルズ応 力と GS と SGS (サブグリッドスケール) 成分の和をとっ たレイノルズ応力を比較すると、両者に地表近傍を除 き有意な差は見られないことも示している。一方、本解 析モデルで得られた動粘性係数に対する渦粘性係数の 比は、最大で 2 倍程度を示している。したがって、本解 析モデルにおいても、SGS成分を含めなくても有意な差 は見られないことが想定され、GSの評価のみで十分で あるものとしている。

\section{2 流入变動風の大気乱流場口拡散場への対応性}

図4,5,6亿障壁の無い場合の煙源の水平位置(解析対 象部流入面より $8 \mathrm{H}$ 下流) における平均速度 (U) と乱流強 度 ( $\bar{u}^{\prime}{ }^{2}$ : 速度変動の標準偏差) の鉛直分布、パワースペ 

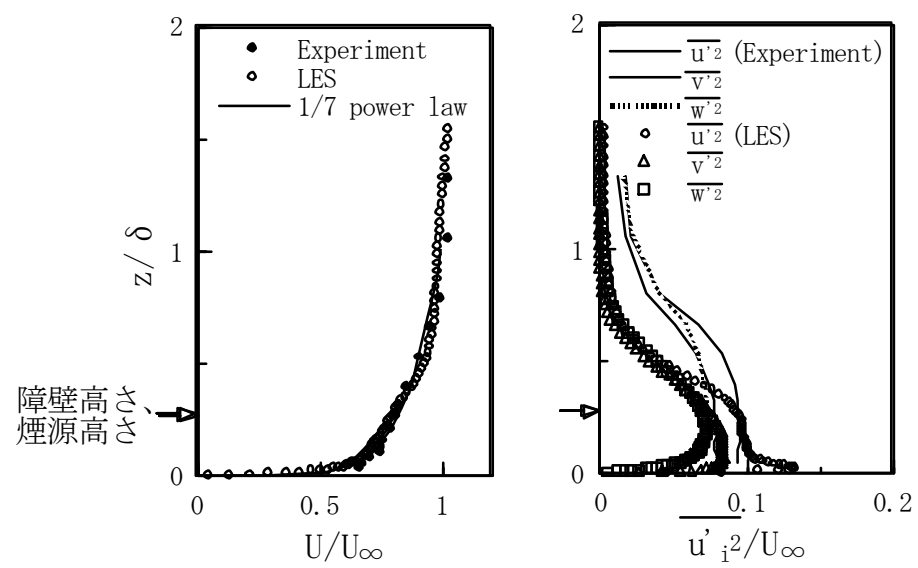

Fig. 4 Vertical profile of mean velocity and turbulence intensity
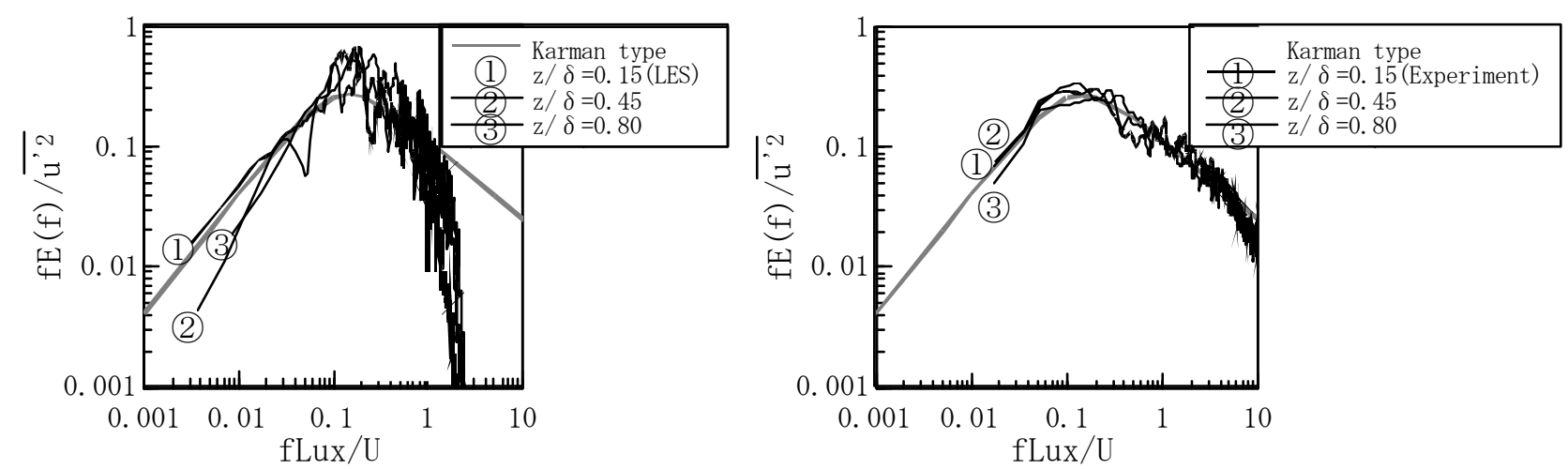

Fig. 5 Power spectrum of velocity fluctuation
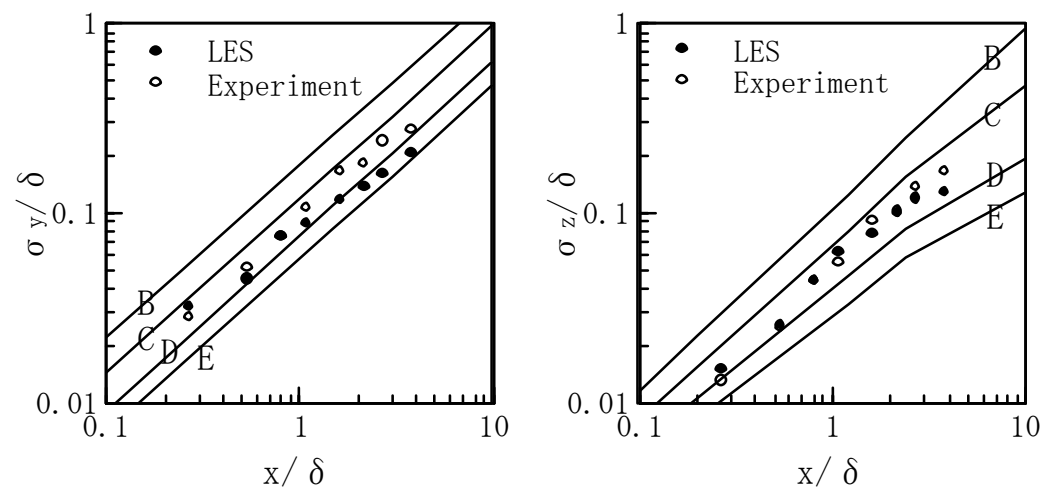

Fig. 6 Spanwise and vertical spreading rates of a plume

クトル $(\mathrm{E}(\mathrm{f}))$ 、水平および鉛直方向の拡散幅 $(\sigma \mathrm{y} ， \sigma \mathrm{z})$ についてそれぞれ示す。なお、平均速度、乱流強度は主 流速度 $\left(\mathrm{U}_{\infty}\right)$ 、パワースペクトルは周波数 $(f)$ 、速度変 動の標準偏差、鉛直方向の拡散幅は境界層厚さ $(\delta)$ で それぞれ規格化されている。大気拡散現象を風洞内で 再現する場合、大気中における拡散幅と相似になる必 要がある。そのため、拡散場の再現を最優先に考え、風 洞実験では測定部入り口に乱流格子、それより下流側 に L 型の 2 次元ラフネスを 5 本地表面に配置し、比較的 上空に至るまで強い速度乱れを持った境界層乱流を空 間発達させている。また、煙源位置では $37 \mathrm{~cm}$ 程度の境 界層厚さ $(\delta)$ が得られ、H/ $\delta=0.27$ としている。一
方、数値計算上においても、地表面に各種ラフネスを配 置させることにより、強い速度乱れを伴う分厚い境界 層乱流を短い助走距離で空間発達させている。その結 果、ラフネス周辺では気流場は強く歪められ欠損が大 きいものの、そこを通過すると徐々に回復し、流出境界 付近では実験結果に良く一致した $1 / 7$ 勾配を持つ変動 風が得られている(図4)。なお、煙源位置における境界 層厚さは $3.7 \mathrm{H}$ となり、したがって、煙源高さ、H/ $\delta$ は 実験同様、0.27である。一方、乱流強度については、境 界層上部に至るまで強い速度乱れを作り出すことはで きず、上空側では急激に減少しているものの、煙源高さ 周辺では各成分とも実験值に相当する乱流強度は十分 
に得られているのが分かる(図 4)。また、図 5 より、風 洞実験ではカルマン型によく整合したスペクトル分布 がいずれの高さ位置において得られているものの、LES では、地表近傍 $(\mathrm{z} / \delta=0.15)$ を除き上空部 $(\mathrm{z} / \delta$ $=0.45,0.80)$ ではカルマン型に対し、高周波側 $(>1)$ お よび低周波側(<0.02)においてもややパワーの小さいス ペクトル分布が得られている。このことは以下のよう に考えられる。まず、低周波側のパワーの減衰について は、平均風速 (U) に対する吹送距離の比が解析領域で捉 えられる最小無次元周波数と見なせ、本解析結果では その無次元周波数を 0.02 程度と算出している。ここで、 本計算結果での低周波側ではいずれの高さ位置におい ても0.02の周波数まではカルマン型によく一致してい るため、乱流場に大きく影響を残寸可能性は低いもの と考えられる。一方、高周波側については、壁座標で表 されたコルモゴロフスケールを1のオーダーとし19)、乱 れのエネルギーの粘性散逸率がコルモゴロフ波数の0.1 倍付近の渦から急激に増加寸るものとした場合 ${ }^{20)}$ 、壁 座標で 10 数 10 程度のスケールの渦からエネルギー が急激に減衰することが知られている。これに基づき、 エネルギーの粘性散逸が急激に増加する乱れスケール を無次元周波数に換算すると $1 \sim 10$ 程度の範囲になる。 本計算結果では、無次元周波数 1 程度からパワーの減 衰が見られ始めており、エネルギーの散逸の激しい周 波数帯とよく対応しているのが分かる。一方で、格子解 像度が高周波のパワーに与える影響についても調心゙る と、本研究では主流方向の格子間隔を 0.04 としている ため、無次元周波数に換算すると 4 程度になる。した がって、高周波成分のパワーの減衰は、格子解像度の影 響よりも低レイノルズ数流れにおける粘性散逸の影響 がやや大きいものと考えられる。このスペクトルの本 研究の有効性については、4.3 節にてふれる。

また、図 6 のPasquil1-Gifford 線図の大気の安定 度に基づいた水平、鉛直拡散幅に着目すると、LES に よって得られたそれぞれの拡散幅は、実験結果と同様 いずれの風下位置においても中立状態における大気拡 散幅 (B: 不安定、C: 弱不安定、 D: 中立、 $E$ : 弱安定) に相 当する分布を示している。

以上のことから、本研究では大気拡散場を再現する ために必要な流入変動風の特性は数值計算上において も得られているものと判断した。

\section{3 障壁周りの乱流構造}

図 7,8 にLES によって得られた障壁周辺における平 均速度と乱流強度の鉛直分布をそれぞれ示す。各統計 量の算出にあたっては、ドライバー部・解析部ともに流 れが十分に行き渡るのを確認してから、無次元時間 100 程度の時間平均をとっている。なお、各図の (a)，(b) は
それぞれ平均速度、乱流強度の主流、鉛直成分を示し、 主流速度により規格化されている。また、実験結果で は、x/H=1, 2, 3, 4, 5, 6, 10の風下位置について示してい る。

障壁の存在により壁上部で強い上昇流が発生するも のの、壁後方 $(\mathrm{x} / \mathrm{H}=2.5 \sim 5.5)$ では逆流、壁よりやや離 れた所 ( $\mathrm{x} / \mathrm{H}=3.5 \sim 5.5)$ での剥離線(図中の点線に相当) 周辺では下降流が形成される。また、地表面への再付着 点は $\mathrm{x} / \mathrm{H}=5.75$ の風下位置で見られた。風洞実験で得ら れた循環域の大きさは最大高さ $1.3 \mathrm{H}$ 、長さ $3.5 \mathrm{H}$ であ るが、LES では最大高さ $1.45 \mathrm{H}$ 、長さ $3.75 \mathrm{H}$ であり、少 しだけ大きいものとなった。また、特に $\mathrm{x} / \mathrm{H}=5,6$ での 鉛直成分の平均流速は実験結果に対し僅かに差違が生 じているものの、全体的には良好に再現している。

次に乱流強度分布について着目すると、壁背後 $(\mathrm{x} /$ $\mathrm{H}=2.5$ ) では、剥離せん断層の活発な摇動(フラッピン グ)により、各成分において剥離線周辺で鋭いピークを 持った乱流強度が得られる。しかしながら、障壁より下 流に向かうにしたがい、剥離せん断層の拡がりや後流 域内一の巻き込みによる渦の生成により地表近傍の乱 流強度は相対的に増大寸る。そのため、各成分において 鉛直方向に対し拡がった分布を示すようになり、特に 主流成分の乱流強度は鉛直方向に対し、一様な分布が 形成されるようになる。また、本研究では、ドライバー 部において得られた流入変動風の乱流強度は、境界層 厚さに対し上空部では十分な速度乱れが得られなかっ たために、障壁後方においても上空では各成分の乱流 強度は実験結果に対し弱くなっている。しかしながら、 後流域内部では実験結果によく整合した乱流強度が得 られている。

次に、図 9,10にLESおよび風洞実験によって得られ た障壁後方での変動風速のパワースペクトル分布を示 す。LESによって得られたパワースペクトル分布は、剥 離せん断層の活発なフラッピングにより、壁背後 $(\mathrm{x} /$ $\mathrm{H}=3$ ) の障壁高さでは地表近傍の場合に比べて無次元周 波数 0.1 近傍のある範囲 $(0.05 \sim 1)$ にわたりパワーの 強い分布が形成され、1より高周波側では急激にパワー が減衰している。また、下流に向かうにしたがい乱流場 の一様化が進み、障壁よりやや離れた後流域内部 ( $\mathrm{x} /$ $\mathrm{H}=4,6)$ の異なる高さ位置 $(\mathrm{z} / \mathrm{H}=0.15,1.0)$ では両者のパ ワースペクトル分布はほぼ類似したものになる。また、 後流域外部 $(z / H=2.0)$ では、いずれの風下位置において も内部に対し全体的にパワーの低い分布を示す。

なお、実験結果では無次元周波数 0.1 周辺でピーク を示し、1程度の高周波側に至るまでエネルギーを伝え ており、それを上回る周波数帯の持つパワーはピーク 周波数の持つパワーに比べて十分に小さくなり、乱流 場に及ぼす影響は小さい周波数帯と見なせる。 
(a)

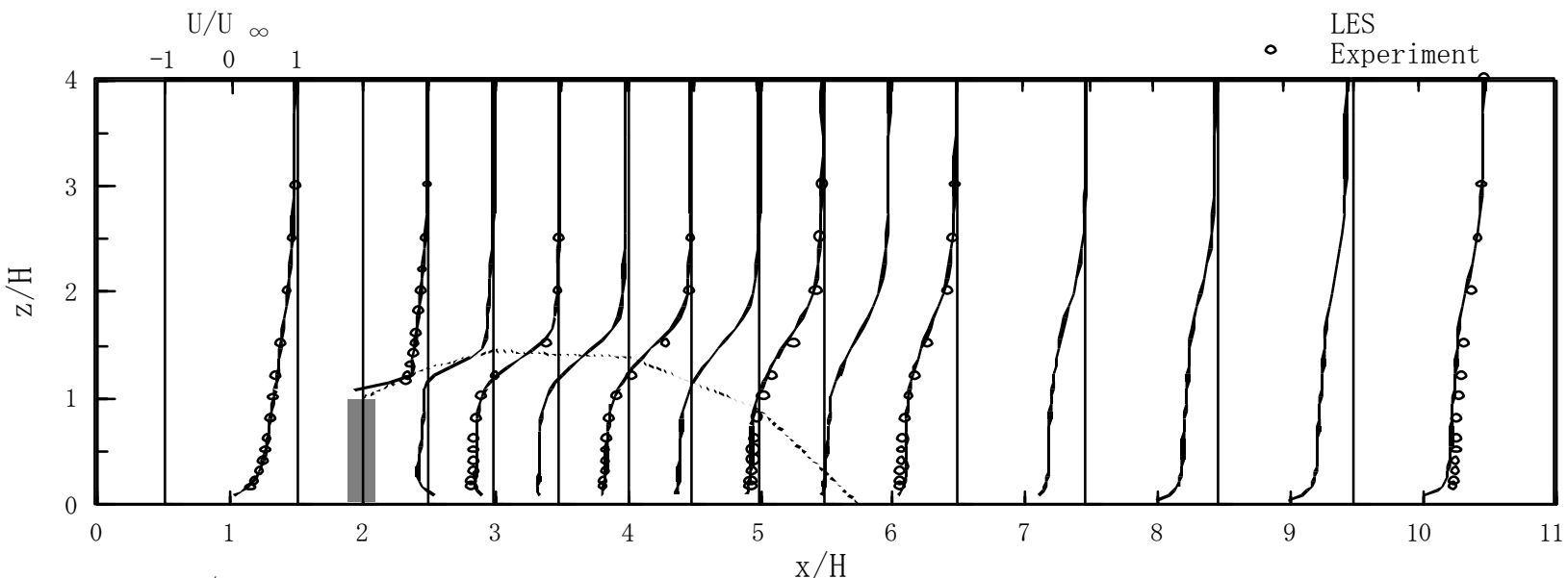

(b)

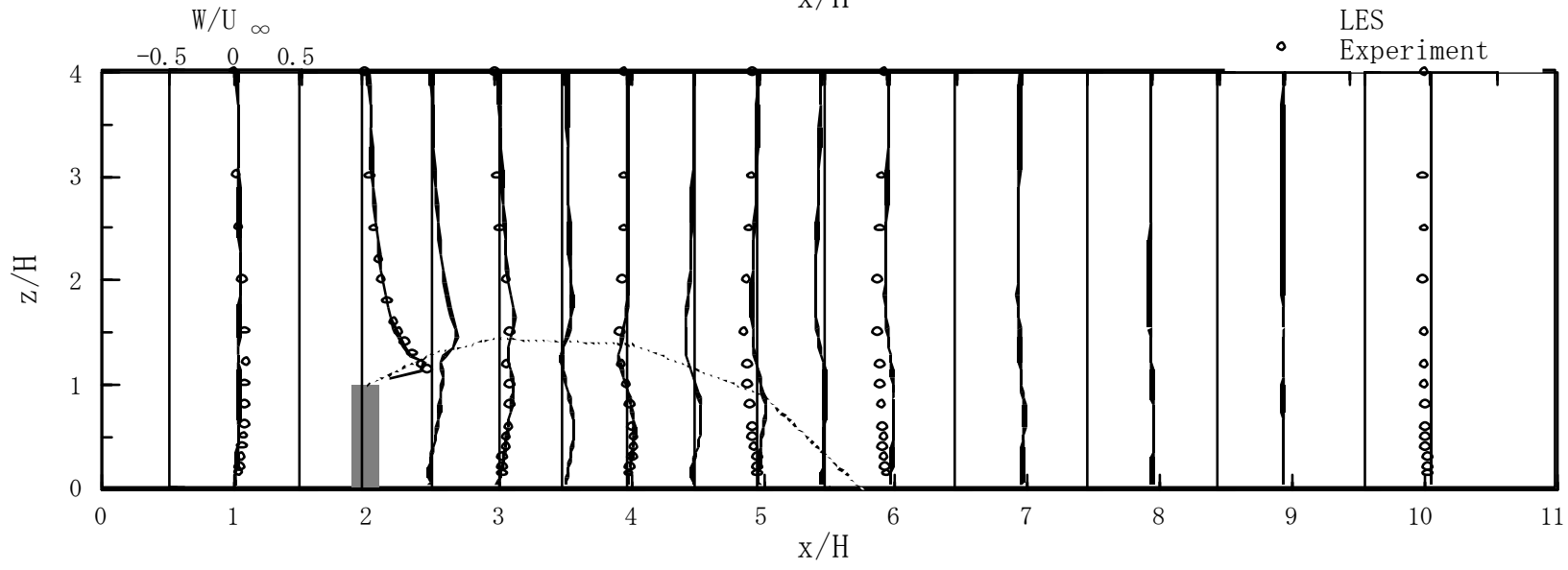

Fig. 7 LES and experimental results for vertical profiles of mean velocity

(a)

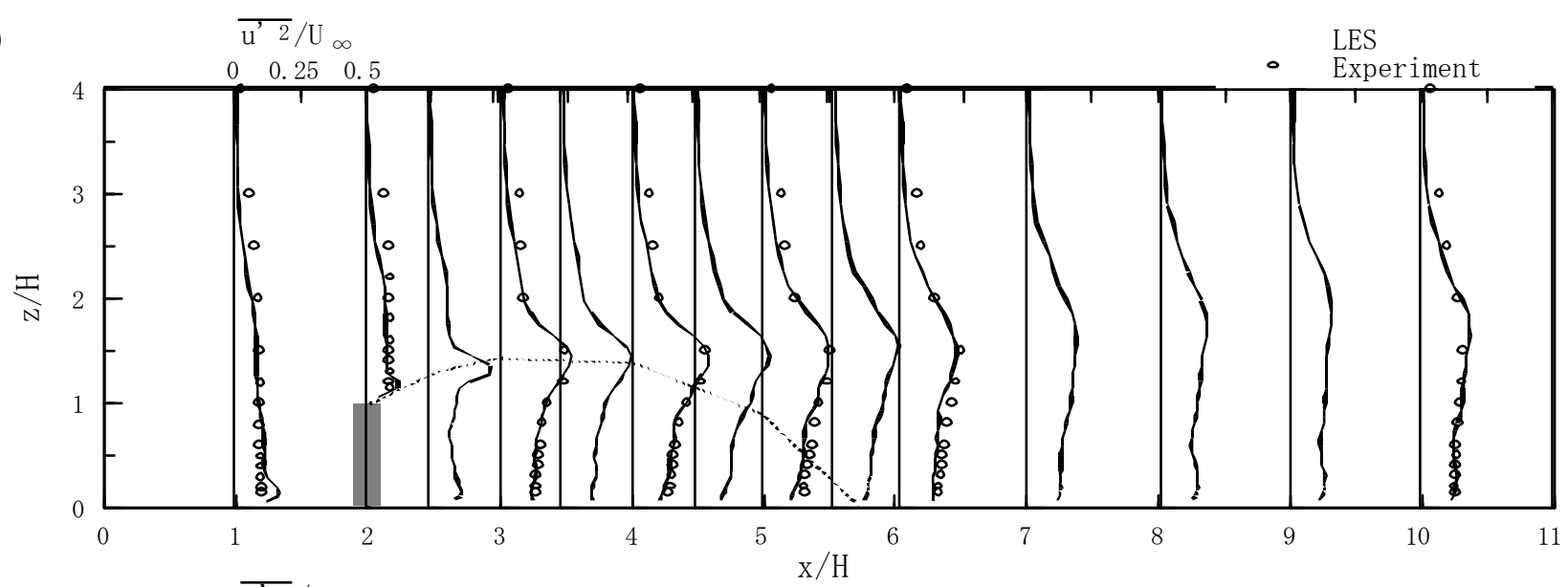

(b)

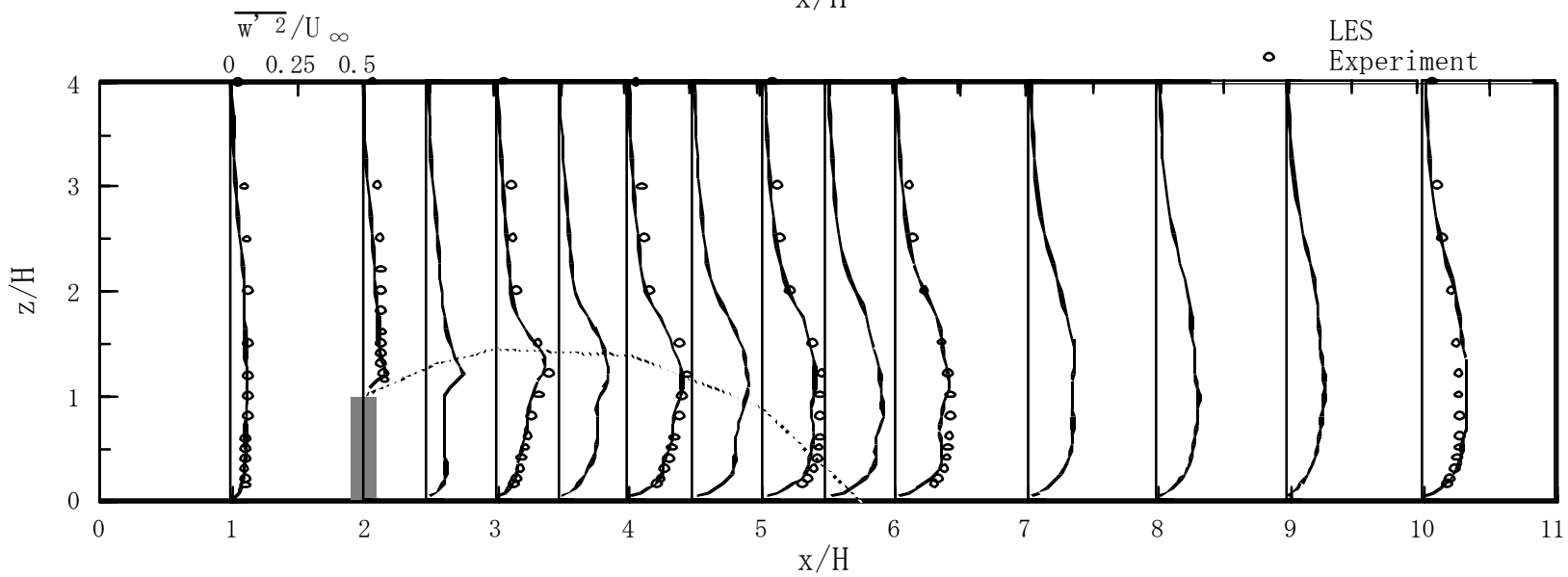

Fig. 8 LES and experimental results for vertical profiles of turbulence intensity 

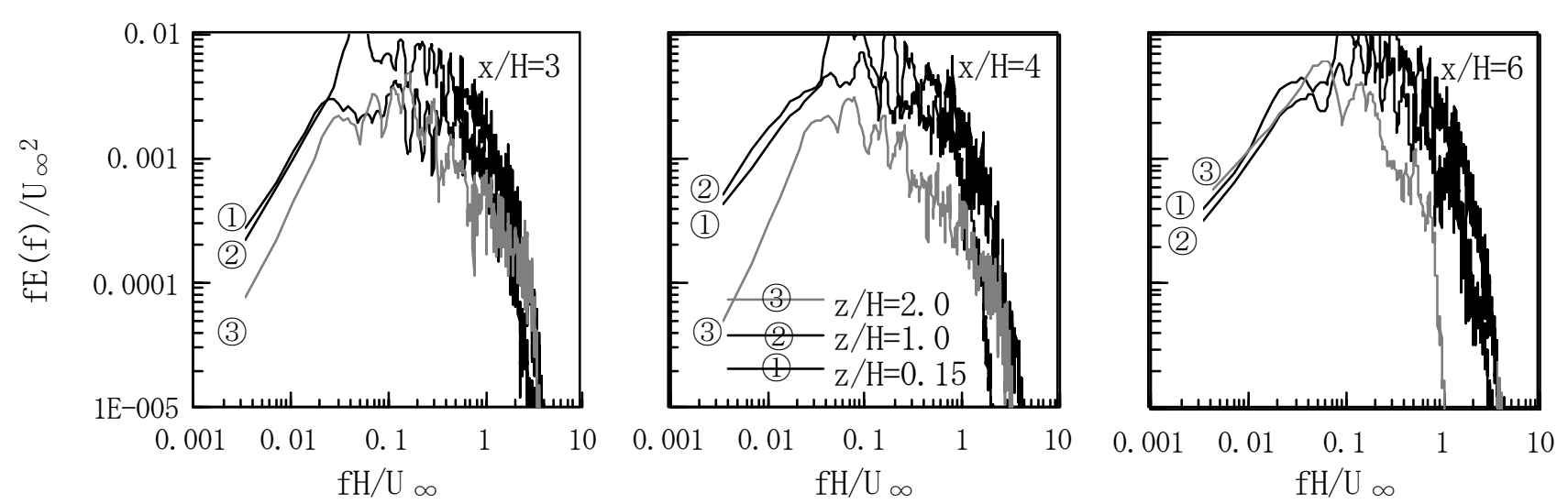

Fig. 9 LES result for power spectra around a normal plate
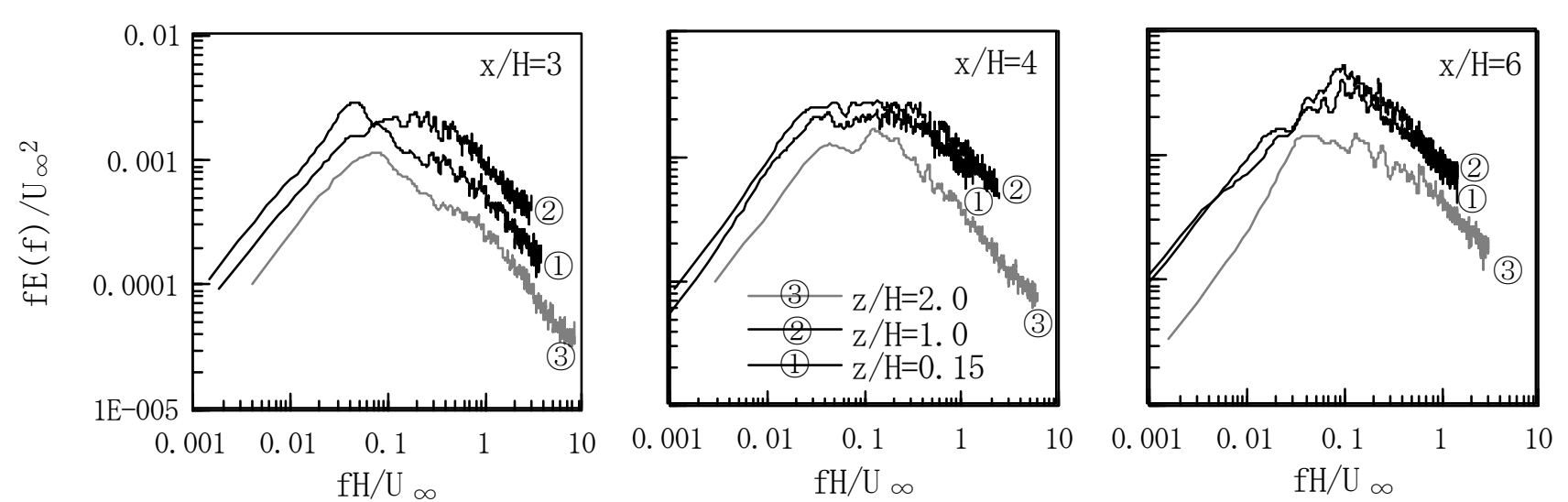

Fig. 10 Experimental result for power spectra around a normal plate

本解析モデルのドライバー部にて有効に捉えられたパ ワースペクトル分布の無次元周波数帯は $0.02 \sim 10$ 範 囲となっているため、数值計算上における障壁後流域 での渦運動を表す支配的な周波数帯は捉えられている ものと判断でき、無次元周波数 $0.02 \sim 1$ で有効な本研 究でのスペクトルは後流域での影響を評価する上では 妥当なものと見なせる。

\section{4 障壁周りの濃度特性}

\section{4.1 濃度の時系列変化}

図 11 に、LES および風洞実験によって得られた (a) 障壁の存在しない平地条件と (b) 障壁の存在する場合に おける濃度の時系列変化をそれぞれ示す。なお、濃度波 形は、 $\mathrm{x} / \mathrm{H}=6$ の風下位置における各高さ (平地条件： $\mathrm{z}$ ) $\mathrm{H}=0.1,1.0,1.6$ 、障壁: $\mathrm{z} / \mathrm{H}=0.1,0.8,1.6)$ について示 している。瞬間濃度 (c) は、主流速度、障壁の高さおよ び煙源強度 $(Q)$ で規格化されている。平地条件におい て、LESによって得られた濃度波形は、プルーム中心軸 $(\mathrm{z} / \mathrm{H}=1.0)$ では瞬間的なピーク濃度が頻繁に発生し、プ ルーム端 $(\mathrm{z} / \mathrm{H}=0.1,1.6)$ では間欠的に濃度のピークが発 生している。また、いずれの高さ位置においても風洞実 験結果に対し、ほぼ類似した濃度波形が得られている。
一方、障壁が存在する場合、後流域外部 $(\mathrm{z} / \mathrm{H}=1.6)$ で はスパイク状の高濃度が頻繁に発生するものの、内部 ( $\mathrm{z} / \mathrm{H}=0.1,0.8)$ では定常的に高い変動を示す濃度波形が 得られている。また、実験結果と比べると、後流域外部 の上空側では乱流強度がやや弱くなっているためにト レーサガスも十分に上空へ拡散されず、全体的に濃度 值がやや小さく評価されている。しかしながら、瞬間的 なピークが頻繁に発生するといった点では、両者は定 性的に一致している。また、後流域内部では変動が抑制 された定常的な濃度波形が得られ、風洞実験の場合と 同様な特徵となっている。

\section{4.2 平均濃度特性}

図 12,13 にESによって得られた平地条件および障 壁の存在する場合の平均濃度 (C)の鉛直分布についてそ れぞれ風洞実験結果と合わせて示す。なお、平均濃度は 主流速度、障壁の高さおよび煙源強度 $(\mathrm{Q})$ で規格化され ている。

平地条件では、トレーサガスは下流に向かうにした がい拡散が進み、徐々に鉛直方向へ拡がった分布を示 す。また、上空のプルーム端周辺では実験結果に対し定 量的にやや低く評価しているものの、いずれの風下位 

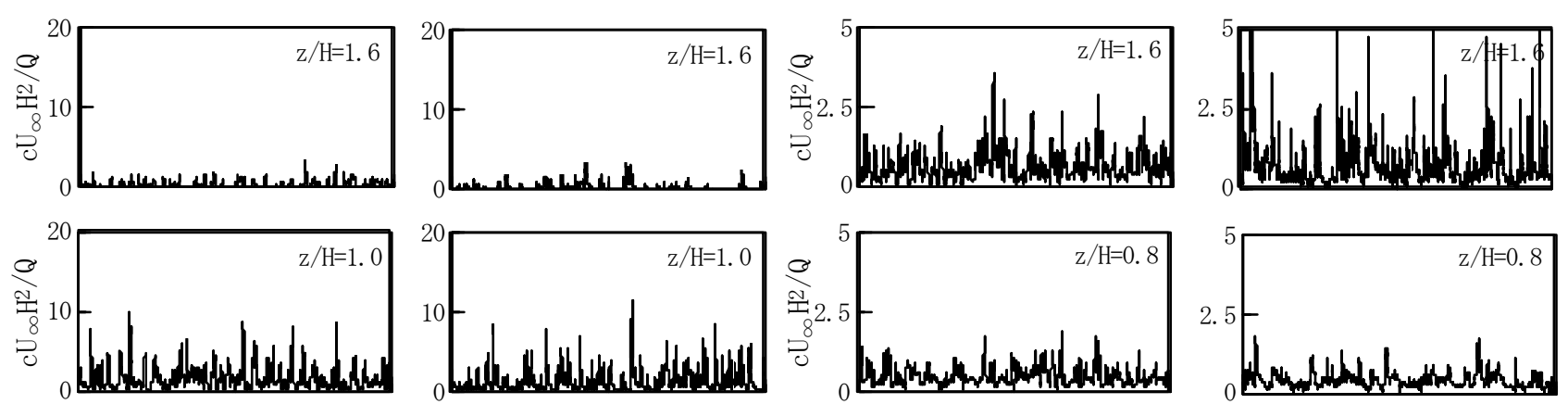

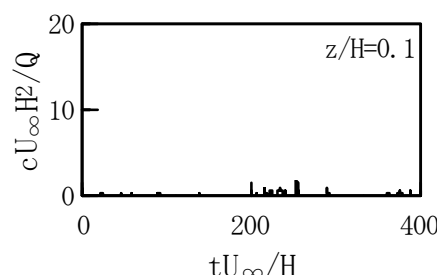

$(a-1)$ LES

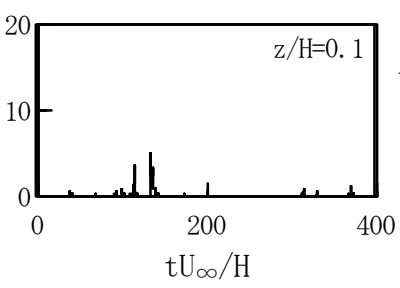

$(a-2)$ Experiment

(a) The case without a normal plate

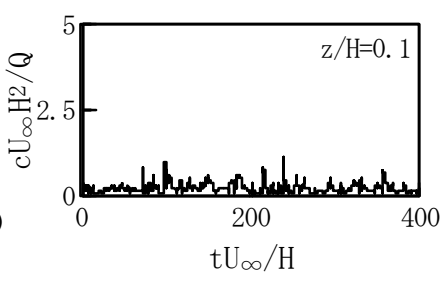

$(b-1)$ LES

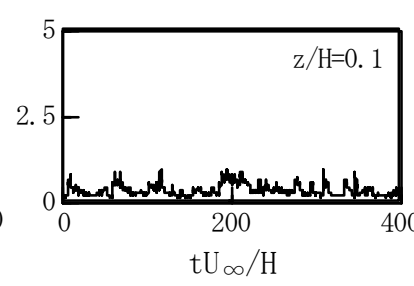

$(b-2)$ Experiment

(b) The case with a normal plate

Fig. 11 Experimental and LES results for time series of concentration fluctuation

置においてもそこを除いた所ではよく一致した平均濃 度分布を示す。

一方で、障壁が存在する場合、壁上流側より放出され たトレーサガスは上昇流の影響により全体的に上空に 強く持ち上げられる。障壁を通過すると剥離線より上 空側で最大の平均濃度を示し、平地条件に対し鉛直方 向へ大きく拡散される。また、剥離せん断層の後流域内 への巻き込みによりトレーサガスは強く連行され、障 壁後方の地表近傍では平地条件に対し高い平均濃度を 示し、障壁高さ付近に至るまで一様な濃度分布が形成 される。風洞実験結果と比較すると、特に障壁後方での 上空のプルーム端では平均濃度がやや小さいのが分か る。また、後流域内での平均濃度分布は、風洞実験の場 合にはほぼ一定になっているものの、数值計算では地 表近傍で十分に格子を与えたことにより、ノイマン境 界条件にしているにも関わらず、その地表から少し離 れれば僅かに勾配が見られる。しかしながら、いずれの 風下位置においても全体的にはよく対応した平均濃度 分布が得られている。

次に、障壁高さにおける水平方向の平均濃度分布に ついて着目し、それを図14に示す。2次元壁について は、既往の拡散実験により、障壁高さにおける平均濃度 水平分布がガウス分布を示すことが確認されている21。 それに対し、本研究の有限幅壁では、後流域での活発な 3 次元運動に伴う濃度場の一様化により、障壁背後 $(\mathrm{x}$ / $\mathrm{H}=2$ ～3) では障壁の横幅まではほぼ平均濃度が一定と なっている。しかしながら、上空に持ち上げられた卜 レーサガスが壁からやや離れた所での剥離渦の生成に 伴う巻き込みにより後流域内一下降していくため、下
流に向かうにしたがい徐々に障壁中心線でピークを示 すようになる。また、風洞実験結果と比較すると、いず れの風下位置においても障壁の横幅までは定量的には おおよそ一致しているものの、プルーム端では拡がり が小さく評価されている。これは、水平方向において も、やはり、接近流の速度乱れの影響に起因寸るもので ある。

\section{4.3 变動濃度特性}

図 15,16にLESによって得られた平地条件および障 壁の存在する場合における r. m. s. 濃度 $\overline{\left(\mathrm{c}^{\prime}{ }^{2}\right.}$ : 濃度変動 の標準偏差)の鉛直分布をそれぞれ風洞実験結果と合わ せて示す。なお、r.m.s. 濃度は主流速度、障壁の高さ および煙源強度で規格化されている。

平地条件において、r.m. s. 濃度はいずれの風下位置 においてもプルーム中心軸 $(\mathrm{z} / \mathrm{H}=1.0)$ で最大を示し、プ ルーム端に向かうにしたがい濃度变動は間欠的になる ため非定常性が強くなり、分布形状としては平均濃度 に比べて緩やかに減少する。また、実験結果と比較する と、r.m.s. 濃度分布においても上空側のプルーム端で やや過小評価されているものの、いずれの風下位置に おいてプルーム中心軸周辺では概ね一致している。

一方、障壁が存在する場合においては、壁背後 (x/ $\mathrm{H}=3$ ) では剥離せん断層の活発なフラッピングにより、 剥離線周辺において高いr.m. s. 濃度を示す。しかしな がら、壁よりやや離れた所 $(\mathrm{x} / \mathrm{H}=4,5)$ では、剥離せん断 層の後流域内一の巻き込みにより、後流域外部での強 い変動性状を持つトレーサガスが内部にその濃度特性 を伝えるようになり、剥離線周辺から地表近傍に渡り 


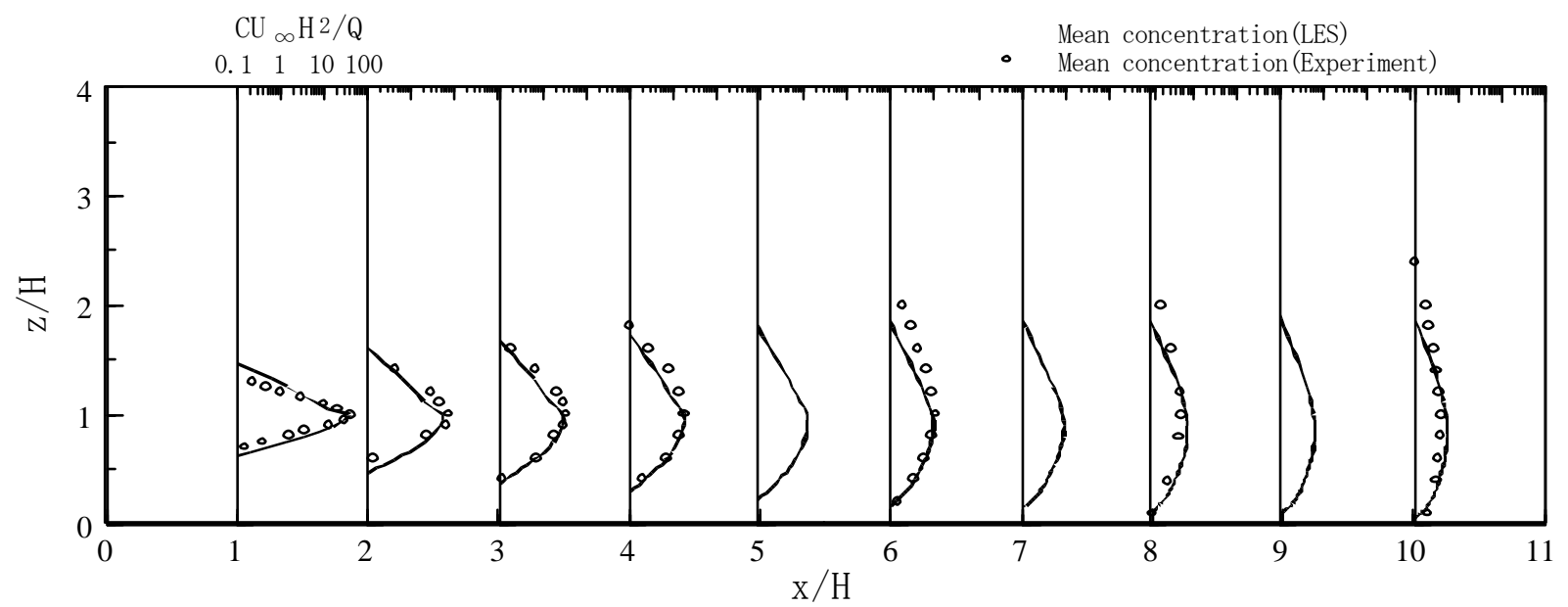

Fig. 12 LES and experimental results for vertical profiles of mean concentration in the case without a normal plate

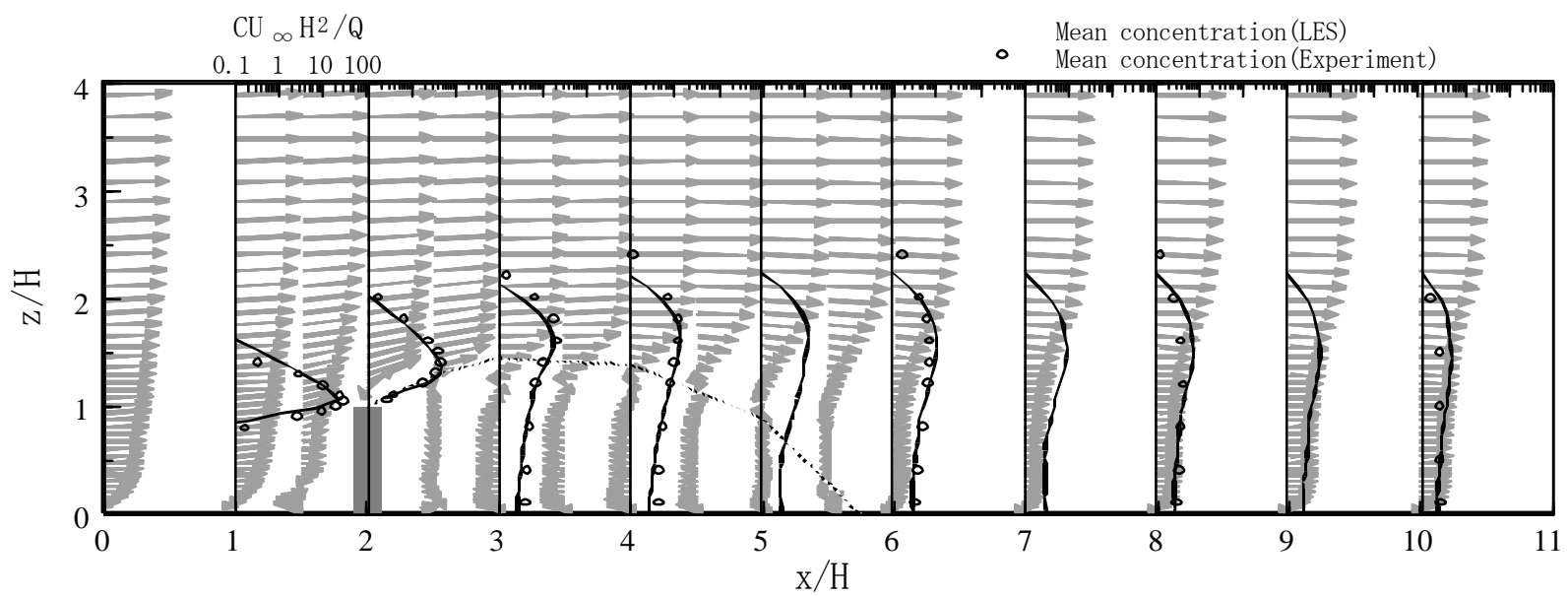

Fig. 13 LES and experimental results for vertical profiles of mean concentration around a normal plate

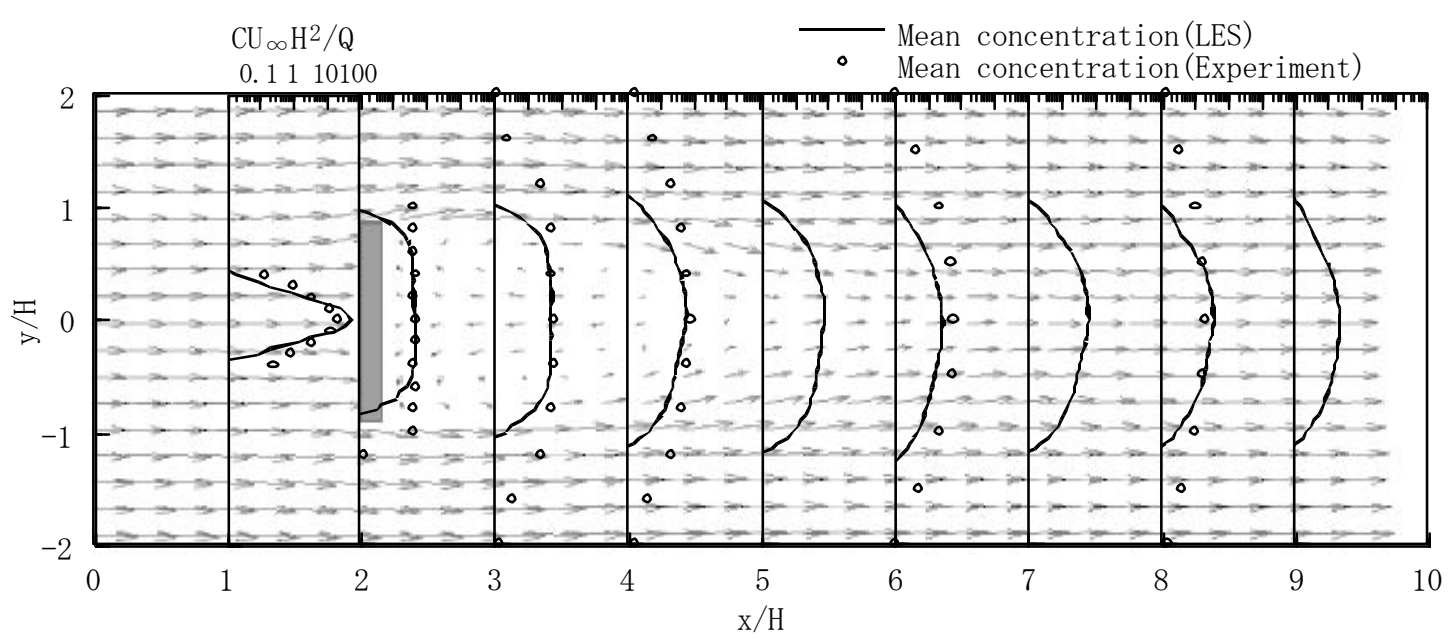

Fig. 14 LES and experimental results for spanwise profiles of mean concentration around a normal plate 


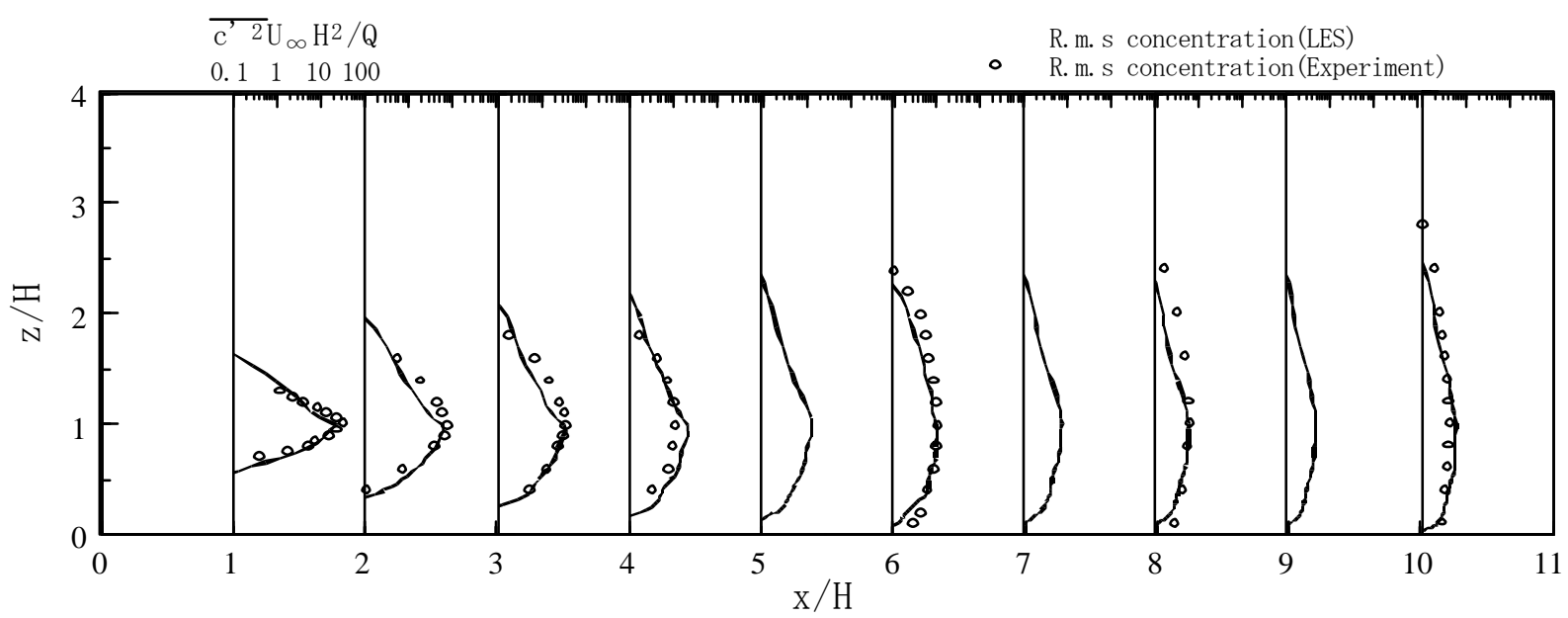

Fig. 15 LES and experimental results for vertical profiles of r.m. s. concentration in the case without a normal plate

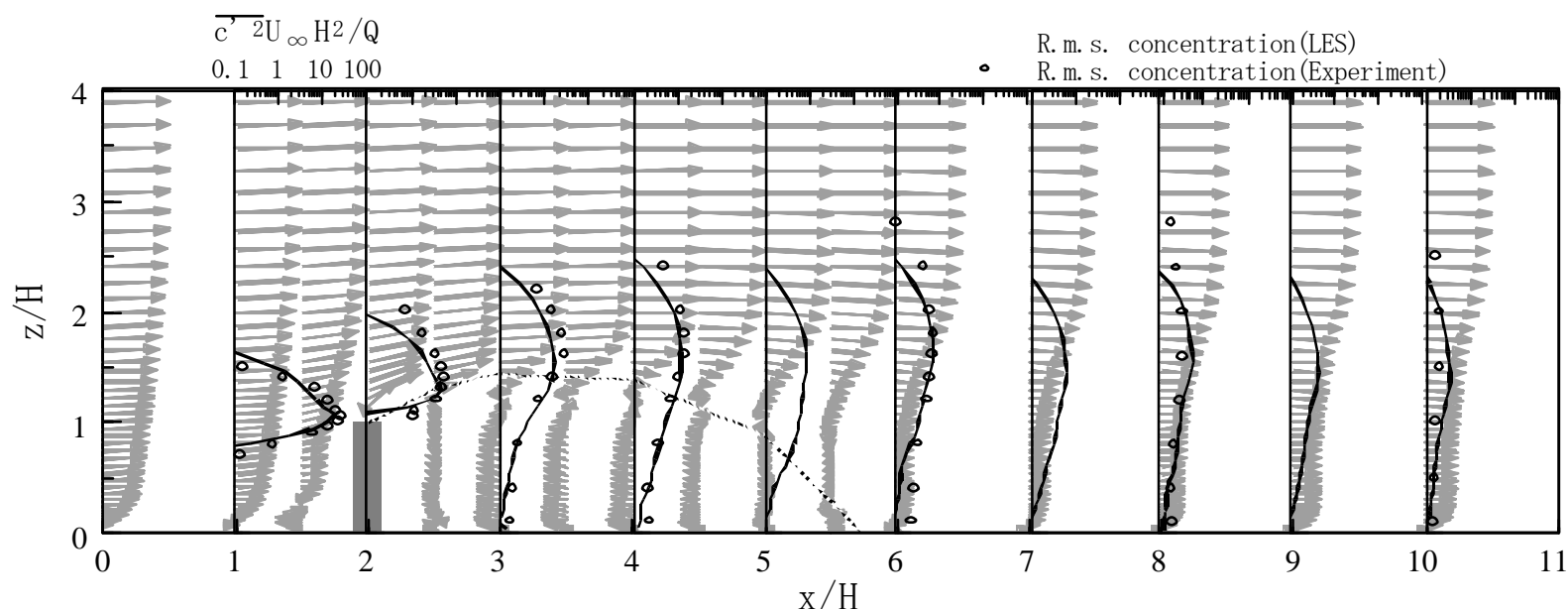

Fig. 16 LES and experimental results for vertical profiles of r.m. s. concentration around a normal plate

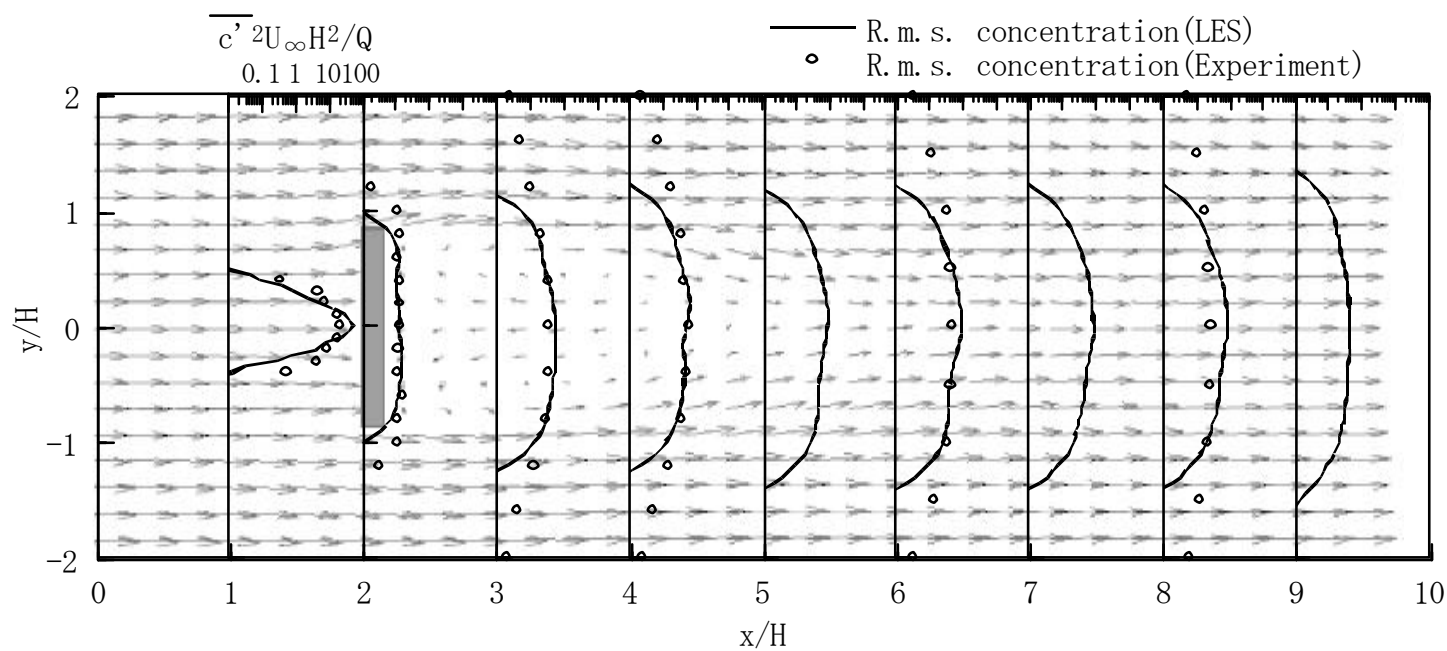

Fig. 17 LES and experimental results for vertical profiles of r.m. s. concentration around a normal plate 


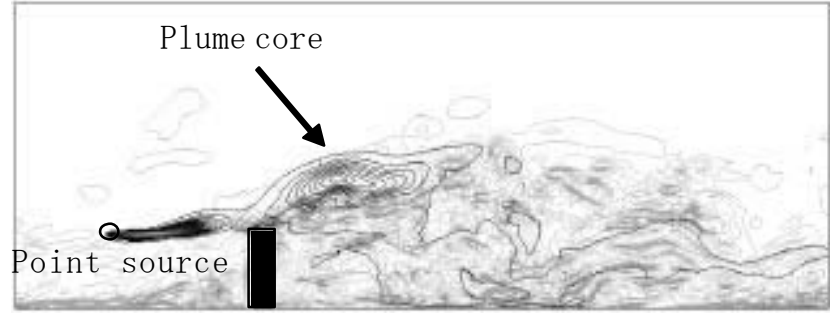

(a) A shot for upward extension of the separated shear layer

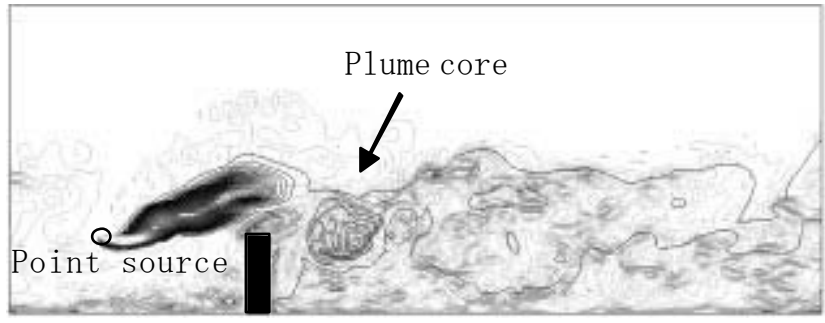

(b) A shot for a rol1-up of the separated shear layer

Fig. 18 Instantaneous contours for vorticity and concentration for various aspects of the separated shear layer
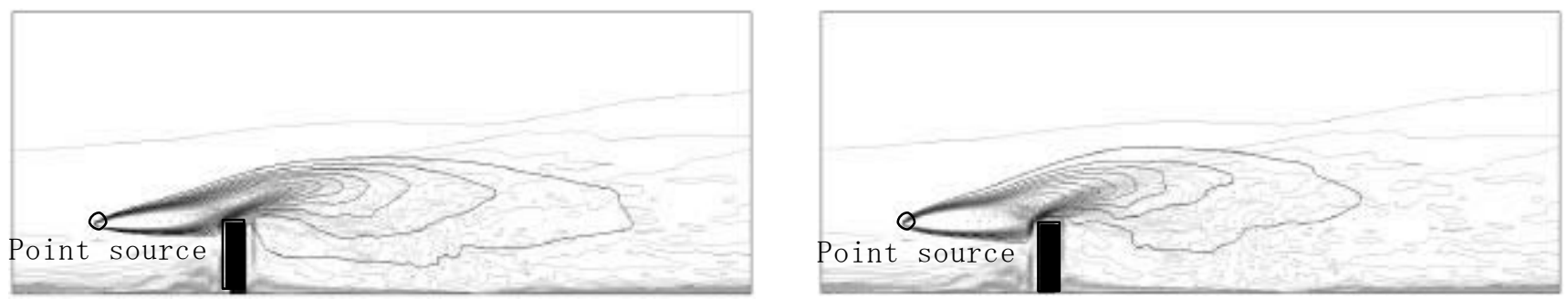

Fig. 19 Contours for mean and r.m. s. concentrations around a normal plate with vorticity contours



(a) The case without a normal plate

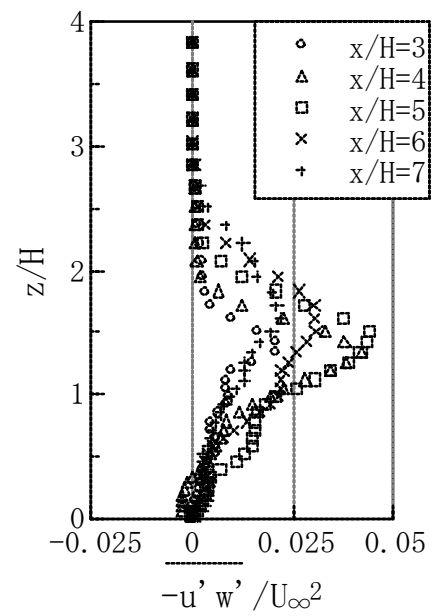

(b) The case with a normal plate

Fig. 20 Vertical profiles of Reynolds shear stress

滑らかに減少するようになる。また、実験值との対応は 平均濃度の場合と同様、上空側のプルーム端を除けば 概ね一致している。

次に、障壁高さにおける水平方向のr.m. s. 濃度分布 を図 17 に示す。r.m.s 濃度の水平分布についても、障 壁背後 $(\mathrm{x} / \mathrm{H}=2$ 2 3) では障壁の横幅まではほぼ一定であ り、下流では壁中心線でピークを示すようになる。しか しながら、プルーム端では濃度変動の間欠性に伴い非 定常性が強まり、緩やかに減少するようになる。また、 実験值と比べると、障壁後方でのプルーム端での拡が
り程度は十分ではないが、障壁横幅内では定量的には おおよそ一致している。

\section{5. トレーサガスの障壁後流域への連行特性}

図 18, 19 に、LES によって得られた障壁周辺におけ る瞬間的な渦度とトレーサガスおよび平均・r. m. s. 濃 度の空間構造をコンターにより示す。

図 18 の (a)では、障壁上部より剥離せん断層の下流 側への伸張によりトレーサガスもそれに同伴され、あ るいは、(b)では剥離せん断層の後流域内一の巻き込み 


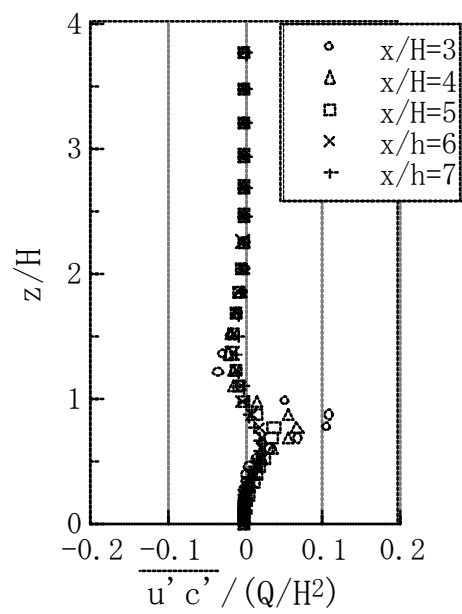

(a) Streamwise concentration flux

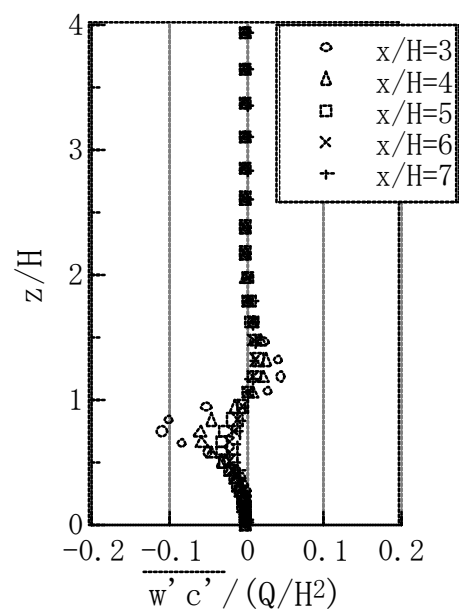

(b) Vertical concentration flux

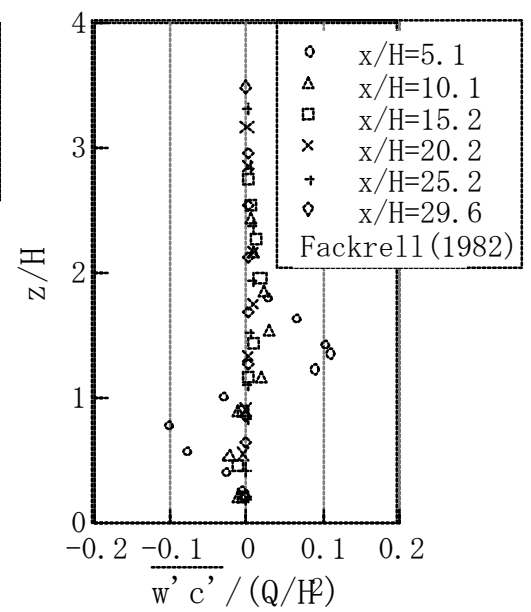

Fig. 21 Vertical profiles of concentration fluxes in the case without a normal plate

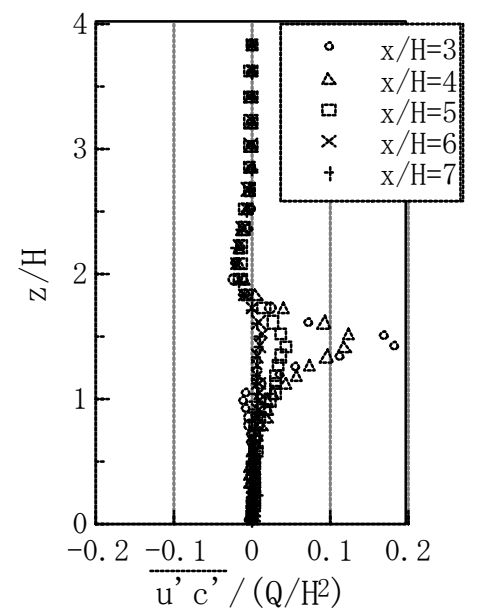

(a) Streamwise concentration flux

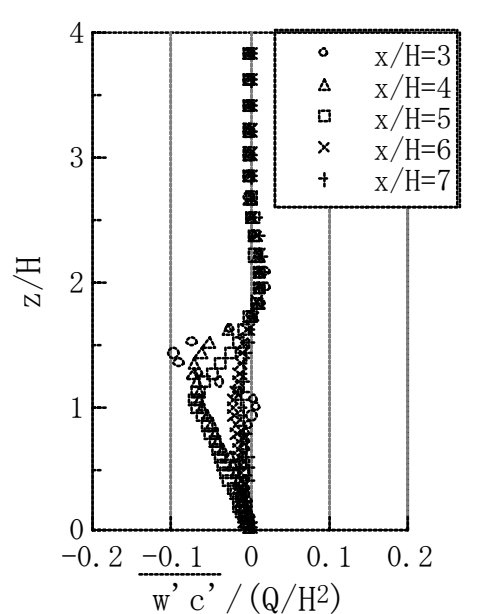

(b) Vertical concentration flux

Fig. 22 Vertical profiles of concentration fluxes in the case with a normal plate

によるトレーサガスも連行される瞬間など、剥離せん 断層の挙動に応じた拡散場の空間構造の様相が分かる。

また、図 19 から平均および濃度変動の高い領域は、 渦度が強く分布しているところよりもやや高い位置で 形成されているのが分かる。

次に、図20にLESによって得られた (a) 平地条件、(b) 障壁の存在する場合の $\mathrm{x} / \mathrm{H}=3,4,5,6,7$ の風下位置にお けるレイノルズ応力 $\left(\overline{\left.-\mathrm{u}^{\prime} \mathrm{w}^{\prime}\right)}\right.$ を示す。なお、レイノル ズ応力は主流速度により規格化されている。

平地条件では、レイノルズ応力はいずれの風下位置 においてもほぼ同様な分布性状を示し、Fackre1122) ら の風洞実験結果に対し、地表近傍から $1.5 \mathrm{H}$ 程度の高さ の範囲まで一定の大きさの分布を示し、その後、上空に 向かうにしたがい徐々に減少する。

一方で、障壁が存在する場合の LES 結果は、壁背後 ( $\mathrm{x} / \mathrm{H}=3)$ では、剥離せん断層のフラッピングにより、レ イノルズ応力が大きくなるものの、そのせん断層の運 動範囲は障壁よりやや高い所に限られるため、地表近 傍に向かうにしたがい急速に減少する。障壁からやや 離れると $(\mathrm{x} / \mathrm{H}=4,5)$ 、剥離せん断層の巻き込みによる渦
の生成により、地表近傍に至るまで活発な運動量輸送 が起こり、鉛直方向に対し拡がった分布を示すように なる。しかしながら、それより下流では渦運動の減衰に 伴い、徐々にレイノルズ応力は小さくなる。

次に図 21,22にLESによって得られた平地条件およ び障壁の存在する場合における濃度フラックスの主流

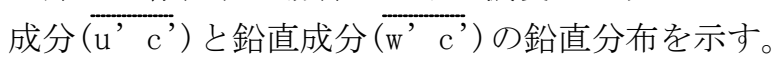

平地条件では、主流、鉛直成分ともに煙源高さを境に 反対称に近い分布形状となっているが、この特性の理 由は、以下のように考えられる。煙源高さを基準に、プ ルームの上空側への拡がりはその中心軸周辺に存在す る高濃度のガス塊が正のw' (変動速度) により上昇する ので、c'(変動濃度) >0より w’c’ は正となる。この場 合、レイノルズ応力との関係から u’c’については負 になる。一方で、地表面側への拡がりは、その中心軸周 辺に存在する高濃度のガス塊が負のw'により下降する ので、やはり c’>0より $\overline{\text { w'c c }}$ は負となり、レイノル ズ応力との関係から $\overline{u^{\prime} \mathrm{c}^{\prime}}$ は正になる。また、それぞ れの絶対值については、いずれの風下位置においても、 煙源高さより下側でのピーク值が大きく、上側では小 


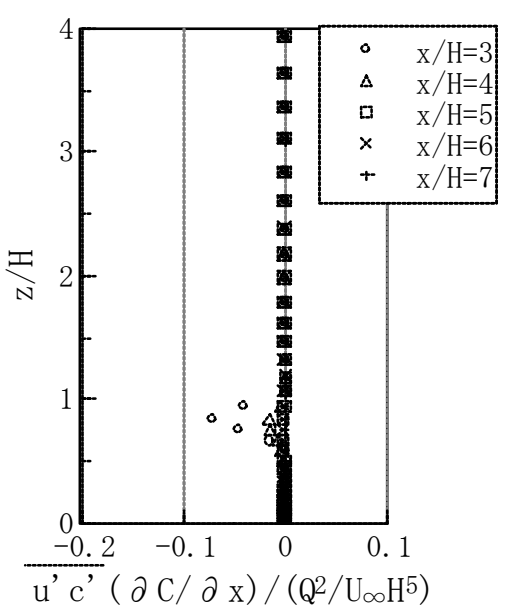

(a) Streamwise production term

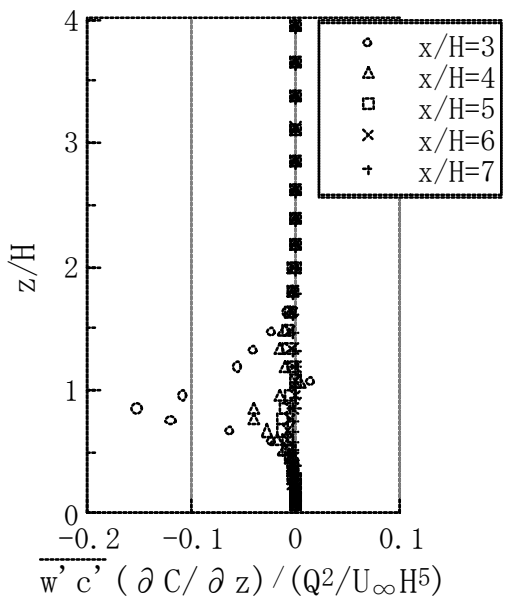

(b) Vertical production term

Fig. 23 Vertical profiles of the production term of concentration fluctuation in the case without a normal plate

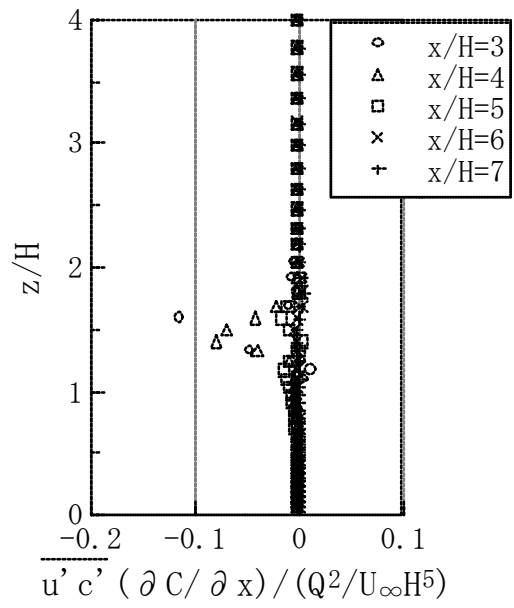

(a) Streamwise production term

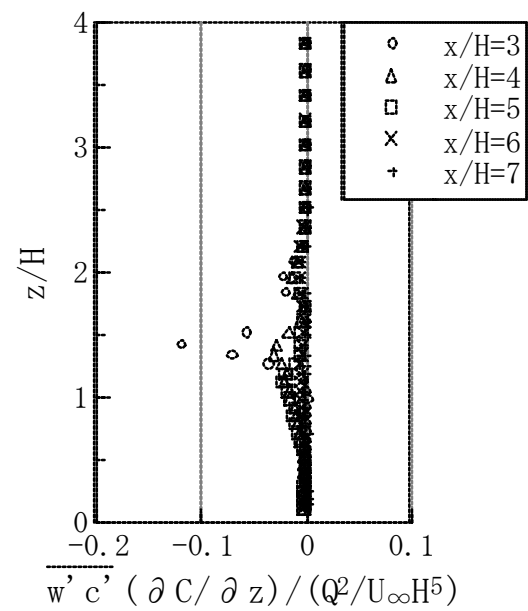

(b) Vertical production term

Fig. 24 Vertical profiles of the production term of concentration fluctuation in the case with a normal plate

さいものとなっている。ただし、Fackre1122) らの風洞 実験結果によると、煙源より $\mathrm{x} / \mathrm{H}=5.1$ の風下位置での 鉛直濃度フラックスは、その上側と下側での絶対值と してのピーク值の差違はあまり見られず、本計算結果 とは異なっている。今回の計算結果については以下の ように考察できる。鉛直濃度フラックスの生成は鉛直 成分の速度乱れに強く関わるが、煙源高さより下側で

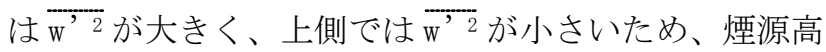
さを境に鉛直濃度フラックスのピークの絶対值が下側 で大きく、上側では比較的小さい分布性状を示す。さら に、濃度フラックスの主流成分の生成は鉛直濃度フ ラックスに強く関わるため、やはり主流成分において も煙源高さを基準に上側と下側での絶対值としての定 量的な差違を持った分布性状が形成される。

次に、障壁が存在する場合、(a) 主流成分では、壁背 後周辺 $(\mathrm{x} / \mathrm{H}=3,4)$ で壁よりやや高い所でピークを示し、 その值も平地条件で得られたものに比心゙、大きくなっ ている。これは、障壁から剥がれたせん断層の動きに応
じて平均流れに強い歪みが生じ、濃度フラックスの生 成が活発に行われたためであると考えられる。一方、 (b) 鉛直成分においては、せん断層のフラッピングの影 響を受け、壁背後 $(\mathrm{x} / \mathrm{H}=3)$ で障壁よりやや高い所でピー クを示すものの、平地条件に比べてそのピークには定 量的な差違はあまり見られない。また、そのせん断層の 活発な運動は障壁後流域内部には至らず、少し下方で 急激に減少する。障壁よりやや離れると $(\mathrm{x} / \mathrm{H}=4,5)$ 、剥 離せん断層の巻き込みによりトレーサガスも活発に連 行され、壁背後 $(\mathrm{x} / \mathrm{H}=3)$ に比べて地表近傍に至るまで拡 がった分布を示すようになる。

以上の濃度フラックスに基づき、LESによって得られ た平地条件および障壁の存在する場合における濃度変 動の輸送方程式中の生成項の (a) 主流 (u' $\mathrm{u}^{\prime} \mathrm{c}^{\prime}(\partial \mathrm{C} / \partial \mathrm{x})$ ) と (b) 鉛直成分 ( 図23,24 に示す。

平地条件において、(a) 主流成分では、特に煙源近傍 $(\mathrm{x} / \mathrm{H}=3)$ で煙源高さより下側に負の鋭いピークを示し、 
上側では非常に小さい值ではあるが、正のピークを示 しているのを確認している。このことから符合に配慮 すると、煙源高さより上側ではごく僅かに濃度変動の 負の生成 (散逸)が行われ、下側では活発な正の生成が 行われているのが分かる。(b) 鉛直成分では、上側と下 側で定量的に異なる2つの負のピークを示しており、比 較的下側の方で活発に濃度変動の正の生成が行われて いる。

一方で、障壁が存在する場合、(a) 主流成分では、壁 よりやや離れた所 $(\mathrm{x} / \mathrm{H}=3 \sim 4)$ に至るまで、それよりや や高い所で平地条件に比べて大きい值を持ったピーク を示し、剥離せん断層の伸張により濃度変動の正の生 成が非常に活発であるのが分かる。また、(b) 鉛直成分 では、壁背後 $(\mathrm{x} / \mathrm{H}=3)$ での剥離せん断層のフラッピング により、障壁よりやや高い所で鋭いピークを示し、活発 な濃度変動の正の生成が行われている。壁よりやや離 れた所 $(\mathrm{x} / \mathrm{H}=4,5)$ では、せん断層の巻き込みに伴い、地 表近傍に向かって滑らかに拡がった分布を示すように なる。この拡がった範囲での正の生成が障壁後流にお ける濃度変動の一様化をもたらしている。

\section{6. 結論}

上流側点源排出されたトレーサガスの障壁周りの拡 散問題について LES を適用し、風洞実験結果と比較す ることにより本数理モデルの検証を行った。さらに、後 流域における乱流場·拡散場の空間構造および両者の関 連性を調心、連行特性の観点から物質輸送の機構につ いて検討した。その結果、以下の知見が得られた。

1 ）流入変動風については、ドライバー部の地表面に 種々のラフネスを配置して、比較的短い吹送距離で境 界層乱流の空間発達させ、そこで得られた時刻歴の乱 流場を解析対象部の流入境界条件として計算ステップ 毎に与える方法を採用した。その結果、煙源を設定した 場所での気流の鉛直分布は、実験值によく整合した $1 /$ 7 勾配を持つ変動風が得られた。また、乱流強度やパ ワースペクトルなどの速度変動性状は、境界層上部の 限られた範囲を除けば、煙源高さ周辺を含め、実験結果 に対し、概ね一致した。さらに、いずれの風下位置にお いても $\mathrm{P}-\mathrm{G}$ 線図の中立状態に相当する大気拡散幅が得 られた。以上より、ここでの流入変動風の作成方法が大 気拡散現象を再現する上で妥当であることを示した。 2) 障壁周辺の乱流場について実験結果と比べると、平 均流速は概ね一致し、乱流強度は後流域外部の上空を 除き、内部でよく整合した。また、障壁後方の乱流構造 については、壁背後 $(\mathrm{x} / \mathrm{H}=3)$ で剥離せん断層がフラッピ ングにより強い速度乱れを発生させるものの、その運 動は壁よりやや高い所に限られる。壁よりやや離れる
と $(\mathrm{x} / \mathrm{H}=4,5)$ 、剥離せん断層の後流域内への巻き込みに よる渦の生成により、地表近傍に至るまで運動量輸送 が活発になり、循環域内では一様な速度変動場が形成 された。

3) 障壁周辺の濃度場を実験結果と比べると、平地条件、 障壁が存在する場合ともに、上空側のプルーム端で平 均・r.m. s. 濃度值は、流入変動風の特性の違いにより やや低く評価されたが、それらを除いた所ではよく整 合した。また、拡散特性として、平均濃度については、 障壁上部で上昇流の影響を強く受け、平地条件に比べ て鉛直方向へ大きく拡散されるものの、剥離せん断層 の巻き込みにより後流域内一強く連行される。そのた め、障壁後方では、障壁高さ付近に至るまで一様な濃度 分布が形成され、地表近傍では平地条件に対し高い值 を示す。水平方向については、後流域での活発な 3 次元 運動に伴う濃度場の一様化により、障壁背後 $(\mathrm{x} / \mathrm{H}=2$ 〜 3) では障壁の横幅まではほぼ平均濃度が一定となって いる。しかしながら、上空に持ち上げられたトレーサガ スが壁からやや離れた所での剥離渦の生成に伴う巻き 込みにより、下流側では徐々に障壁中心線でピークを 示すようになる。一方、r.m. s. 濃度については、剥離 せん断層のフラッピングにより、壁背後 $(\mathrm{x} / \mathrm{H}=3)$ では剥 離線周辺で局所的に高いr.m.s. 濃度を示すものの、壁 よりやや離れた所 $(\mathrm{x} / \mathrm{H}=4,5)$ では、剥離せん断層の後流 域内への巻き込みにより、後流域外部での強い変動性 状を持つトレーサガスが内部にその特性を伝えるよう になり、剥離線周辺から地表近傍に向かって滑らかに 減少する。水平方向については、障壁背後 $(\mathrm{x} / \mathrm{H}=2 \sim 3)$ では障壁の横幅まではほぼ一定であり、下流では壁中 心線でピークを示すようになる。しかしながら、プルー ム端では濃度変動の間欠性に伴い非定常性が強まり、 緩やかな減少を示す。

4) 濃度フラックスについては、平地条件では主流、鉛 直成分ともに煙源高さを境に反対称に近い分布性状を 示す。一方、障壁が存在する場合、主流濃度フラックス は、剥離せん断層の伸張による平均流れの強い歪みに より、壁より離れた所に至るまで $(\mathrm{x} / \mathrm{H}=3 \sim 4)$ 活発に生 成されるため、障壁よりやや高い所で平地条件のもの よりも大きい值でピークを示す。鉛直成分では、せん断 層のフラッピングにより、壁背後 $(\mathrm{x} / \mathrm{H}=3)$ では障壁より やや高い所でピークを示すものの、その值は平地条件 とあまり変わらない。しかしながら、壁よりやや離れる と $(\mathrm{x} / \mathrm{H}=4,5)$ 、せん断層の巻き込みによりトレーサガス は活発に連行されるため、地表近傍に至るまで拡がっ た分布を示す。

5 ) 濃度変動の生成機構については、平地条件での主流 成分は、煙源高さより上側では僅かに濃度変動の散逸 が見られ、下側では活発に生成が行われる。鉛直成分で 
は、上側下側ともに生成が行われ、特に下側ではその生 成は活発である。一方、障壁が存在する場合、主流成分 では、壁よりやや離れた所 $(\mathrm{x} / \mathrm{H}=3 \sim 4)$ に至るまで、剥 離せん断層の伸張により、濃度変動の生成は非常に活 発であり、平地条件のものよりも大きいピーク值を示 す。鉛直成分では、壁背後 $(\mathrm{x} / \mathrm{H}=3)$ での剥離せん断層の フラッピングにより障壁よりやや高い所で活発に生成 され、壁よりやや離れた所 $(\mathrm{x} / \mathrm{H}=4,5)$ ではせん断層の巻 き込みにより地表近傍に向かって若干の生成が見られ、 この生成が後流域での濃度変動の一様化をもたらす。

\section{参考文献}

1) Robins, A. G. and Castro, I.P. :A Wind Tunnel Investigation of Plume Dispersion in The Vicinity of A Surface Mounted Cube- II . The Concentration Field, Atmos. Environ. , 11, 299-311, (1977)

2) Ogawa, Y. , Oikawa, S. and Uehara, K. :Field and Wind Tunnel Study of The Flow And Diffusion around A Model Cube-II. Nearfield and Cube Surface Flow and Concentration Patterns, Atmos. Environ. , 6, 1161-1171, (1983)

3) 老川進、石原孟、安田龍介、西村浩一、長谷実: 建物近 傍拡散の予測に関する基礎的研究、その 1 風洞実験: 大 気環境学会誌, 34, 2, 123-136, (1999).

4) Huber, A. H. and Snyder, W. H. :Wind Tunnel Investigation of The Effects of A Rectangular-Shaped Building on Dispersion of Effluents from Short Ad jacent Stacks, Atmos Environ. , 16, 2837-2848, (1982)

5) Li, W. W. and Meroney, R. N. :Gas Dispersion near A Cubical Model Building. Part II . Concentration Fluctuation Measurments, J. Wind. Eng. Ind. Aerodyn. , 12, 3547, (1983).

6) 老川進、孟岩: 建物後流における短時間ピーク濃度の性 状について, 大気環境学会誌, 33, 3, 151-163, (1998)

7) 佐藤歩、佐田幸一: 単独建屋後流におけるトレーサガ ス濃度変動に関する風洞実験, 土木学会論文集 No. 706/ VII-23, 41-49, (2002)

8)Wilson, D. J. and Netterville, D. D. J. : Interaction of A Roof-level Plume with A Downwind Building, Atomos. Environ. , 12, 1051-1059, (1978)

9) 西村浩一、安田龍介、伊藤誠一:建物近傍拡散の予測に 関する基礎的研究, その $2 \mathrm{k}-\varepsilon$ モデルによる数值シミュ レーション, 大気環境学会誌, 34, 2, 103-122, (1999)

10) Germano, M. , Piomelli, U., Moin, P. and Cabot, W. H. : A Dynamic Subgrid-scale Eddy Viscosity Model, Phys. Fluids, A, 3, 7, 1760-1765, (1991)
11) Moin, P. , Squires, K. , Cabot, W. and Lee, S. :A Dynamic Subgrid-scale Model for Compressible Turbulence and Scalar Transport, Phys. Fluids, A, 3, 11, 27462757, (1991)

12) Sykes, R. I. and Henn, D. S. :Large-Eddy Simulation of Concentration Fluctuations in A Dispersing Plume, Atomos. Environ., 26, 3127-3144, (1992)

13)佐田幸一、佐藤歩: 大気境界層中のトレーサガス濃度 変動を対象とした数值計算 (LESに基づく数值計算手法), 日本機械学会論文集(B) 66, 651, 48-54, (2000)

14）中山浩成、田村哲郎、佐田幸一: 上流側点源放出され たトレーサガスの障壁後流域一の連行特性について, 日 本風工学会誌, 95, 159-160, (2003)

15) Tamura, T., Nakayama, H. and Sada, K. :A Fluctuating Dispersion Plume and Its Entrainment in The Wake of A Normal Plate with Finite Width, Proceedings of International Workshop on Physical Mode1ling of Flow and Dispersion Phenomena, Firenze University Press, 235-243, (2003)

16) Smagorinsky. : General Circulation Experiments with The Primitive Equations. Monthly Weather Review, 91, 3, 99-164, (1963)

17) Yabe, T. and Takei, E. :Yabe T. and Takei E. :A New Higher-Order Godunov Method for General Hyperbolic Equations, J. Phys. Soc. Japan, 57, 8, 25982601, (1988)

18) 坪倉誠、小林敏雄、谷口伸行: 差分法ダイナミックSGS モデルに適した等方渦粘性型 SGS モデルの構築とその 平板チャネル乱流における評価, 日本機械学会論文集 (B) 66, 648, 1975-1983, (2000)

19) Kim, J., Moin, P. and Moser, R. :Turbulence Statistics in Fully Developed Channel Flow at Low Reynolds Number, J. Fluid. Mech, 177, 133-166, (1987) 20) Chapman, D. R. :Computational Aerodynamics Development and Outlook, AIAA Journa1, 17, 1293-1313, (1979)

21) 二家本晃造: 東京工業大学大学院総合理工学研究科環 境理工学創造専攻 修士論文, (1999)

22) Fackre11, J. E. and Robins, A. G. : Concentration Fluctuations and Fluxes in Plumes from Point Sources in A Turbulent Boundary Layer, J. Fluid. Mech, 117, 126, (1982) 